\title{
ARTYKUtY
}

Klio. Czasopismo poświęcone dziejom Polski i powszechnym

PL ISSN 1643-8191, t. 38 (3)/2016, s. 17-55

(c) (i) $\Theta$

http://dx.doi.org/10.12775/KLIO.2016.031

BARBARA TECHMAŃSKA*

\section{Szkolnictwo dla mniejszości narodouych na Dolnym Śląsku w okresie PRL. Wybrane zagadnienia}

\section{Education for ethnic minorities in Lower Silesia during the communist era. Selected Issues}

Streszczenie: Artykuł prezentuje wybrane zagadnienia szkolnictwa mniejszościowego na Dolnym Śląsku w PRL. Region ten po II wojnie światowej, oprócz Polaków, zamieszkiwali Żydzi, Ukraińcy, Niemcy, Czesi, Grecy i Macedończycy. Ta skomplikowana sytuacja narodowościowa miała również istotny wpływ na organizację systemu oświaty na tym terenie. Nie wystarczyło bowiem zorganizować go dla dzieci i młodzieży polskiej, ale istniała konieczność uwzględnienia wszystkich przebywających tu mniejszości. Analizie poddany został zasięg terytorialny, zakres chronologiczny, wymiar ilościowy, kwestie dotyczące kadry pedagogicznej, braku podręczników dla szkolnictwa z niepolskim językiem nauczania oraz problemy bazy materialnej. Autorka starała sic̨ ukazać dynamikę zmian - w czasie, w przestrzeni i z uwzględnieniem zróżnicowania narodowościowego. W tekście nie zabra-

* Instytut Historyczny, Uniwersytet Wrocławski, ul. Szewska 49, 48-300 Wrocław; e-mail: batech@wp.pl. 
kło też przypomnienia podstawowych aktów prawnych regulujących kwestie szkolnictwa oraz instytucji, które zajmowały się szkolnictwem dla mniejszości narodowych.

Abstract: The article presents selected issues of minority education in Lower Silesia in the Polish People's Republic. This region after World War II not only Poles lived Jews, Ukrainians, Germans, Czechs, Greeks and Macedonians. This complex situation nationalities also had a significant impact on the organization of the education system in this area. It was not enough for him to arrange for children and young Polish, but there was a need to take account of all minorities residing here. The analysis has been subjected to territorial scope, range chronological, quantitative dimension, issues concerning the teaching staff, lack of textbooks for the education of non-Polish language teaching and the problems of the material base. The author tried to show the dynamics of change - in time, in space and taking into account ethnic diversity. In the text there were also reminders of basic laws governing education, and the institutions that dealt with education for minorities.

Słowa kluczowe: szkolnictwo dla mniejszości narodowych, Dolny Śląsk, Rozporządzenia Ministerstwa Oświaty, szkoły, klasy, komplety: greckie, macedońskie, żydowskie, niemieckie, czeskie, ukraińskie

Keywords: education for minorities, Lower Silesia, the Ordinance of the Ministry of Education, school, class, sets: Greek, Macedonian, Jewish, German, Czech, Ukrainian Wyniku przesunięć granicznych, a później procesów migracyjnych,
Polska stała się państwem w zasadzie jednolitym narodowo. W porównaniu z II Rzeczpospolitą, gdzie mniejszości ${ }^{1}$ stanowiły ponad 30\%

1 Termin „mniejszości narodowe” nie jest definiowany jednolicie. Dla przykładu propozycja J. Tomaszewskiego: „mniejszością narodową nazywać będziemy społeczność (grupę ludzi) obywateli państwa, którzy wyróżniają się od pozostałych obywateli dominujących w tym państwie swą świadomością narodową. Warto zauważyć, że najczęściej towarzyszą temu różnice języka, lecz nie jest to warunek konieczny”, cyt. za: J. Tomaszewski, Mniejszości narodowe w Polsce w XX wieku, Warszawa 1991, 8-9; K. Kwaśniewski definiuje mniejszość narodową jako „kategorię lub podgrupę osób wyróżniających się odrębnością etniczną (języka, kultury, tradycji i ewentualnie także innych cech), które w zasadzie są allochtonami i nie mają autonomii terytorialnej w kraju, w którym decydują się żyć, a w którym ze względu na swoją liczebność nie stanowią najważniejszego narodu państwowego. Są zbiorowością osób pragnących zachować elementy tej narodowej odrębności, a czasem i przekazać je dzieciom, nie zrywając więzi z państwem w którym żyją i z którym czują się związani. Chcą natomiast zachować odrębność kulturową bez naruszania 
ogółu ludności, w Polsce Ludowej odsetek ten wynosił w latach pięćdziesiątych XX wieku 2-2,5\%2. Były jednak regiony kraju, w których grupy mniejszościowe były dosyć liczne. Taki obszar stanowił Dolny Śląsk ${ }^{3}$. Jako część Ziem Zachodnich i Północnych, na których pozostała tylko niewielka grupa dotychczasowych mieszkańców (Niemców i autochtonów) wydawał się „osadniczo bardzo chłonny”, stąd kierowano na niego przesiedleńców z Kresów Wschodnich, reemigrantów, Ukraińców i Łemków z akcji „Wisła”, Żydów ${ }^{4}$, Greków i Macedończyków. Z kolei Czesi znaleźli się na nim w związku ze zmianami w przebiegu granicy południowej. Ta skomplikowana sytuacja narodowościowa na Dolnym Śląsku miała również istotny wpływ na organizację systemu oświaty na tym terenie. Nie wystarczyło zorganizować go dla dzieci i młodzieży polskiej, bowiem istniała konieczność uwzględnienia wszystkich przebywających tu mniejszości.

$\mathrm{Z}$ uwagi na specyfikę omawianego obszaru, w niniejszym artykule analizie poddany zostanie zasięg terytorialny, zakres chronologiczny, wy-

politycznej lojalności wobec państwa zamieszkania”, cyt. za: K. Kwaśniewski, Socjologia mniejszości a definicja mniejszości narodowych, „Sprawy Narodowościowe” 1992, nr 1, s. 56. Także A. Florczak podkreśla złożoność problemu, wymieniając elementy, którymi charakteryzuje się mniejszość narodowa: „pozostawanie mniejszości w stosunku do reszty ludności w państwie, świadomość innej przynależności narodowej, odrębne pochodzenie etniczne, kultura, tradycja, religia i język oraz dążenie do kultywowania cech narodowych i kulturowych", cyt. za: A. Florczak, Mniejszość narodowa, [w:] Encyklopedia politologii, t. 5: Stosunki międzynarodowe, red. T. Łoś-Nowak, Kraków 2002. W przypadku PRL należy pamiętać, że poszczególne mniejszości były „dostrzegane” przez państwo w różnych okresach i w zależności od „aktualnej linii politycznej”.

${ }^{2}$ J. Tomaszewski, op. cit., s. 10.

${ }^{3}$ Po II wojnie światowej terytorialnie funkcjonował Okręg Administracyjny Dolnego Śląska, na bazie którego utworzono województwo wrocławskie. Przy rozważaniach na temat polityki oświatowej to województwo wrocławskie będzie podlegało analizie ze względów statystycznych (jako że oświata znajdowała się pod zarządem Kuratorium Okręgu Szkolnego Wrocławskiego).

${ }^{4}$ Istniała nawet koncepcja stworzenia osiedla żydowskiego na terenie Dolnego Śląska. Region wydawał się odpowiednim miejscem: miał rozbudowaną strukturę miejską, brakowało możliwości konfliktów majątkowych. Żydzi wracający do swoich domów w Polsce centralnej czy południowej często zastawali nowych właścicieli - Polaków, którzy nie mieli ochoty na zwrot mienia byłym mieszkańcom. Na Ziemiach Odzyskanych można było rozpocząć życie od nowa z nadzieją, że nastroje antysemickie w nim nie przeszkodzą. 
miar ilościowy 5 , kwestie dotyczące kadry pedagogicznej, braku podręczników dla szkolnictwa z niepolskim językiem nauczania oraz problemy bazy materialnej. Niezmiernie istotnym wątkiem będzie też ukazanie dynamiki zmian zachodzących w czasie i przestrzeni oraz procesów wynikających ze zróżnicowania narodowościowego.

Liczebność poszczególnych grup narodowych podlegała wahaniom, przede wszystkim w pierwszym 25-leciu PRL ${ }^{6}$. Miało to związek z polityką wysiedlania Niemców w pierwszych latach powojennych czy - później - z ich wyjazdami zainicjowanymi akcją „łączenia rodzin”. Także liczba ludności żydowskiej zmieniała się. Żydzi wyjeżdżali najpierw do państw zachodnich, a następnie do nowo powstałego Izraela. Również po 1956 roku wśród repatriantów przybyłych do Polski z ZSRR sporą grupę stanowili Żydzi, co miało tylko na krótko wpływ na statystyki, ponieważ większość z nich potraktowała Polskę jako państwo tranzytowe. Przyjazd do Polski Greków i Macedończyków uwarunkowany był wojną domową w Grecji ${ }^{7}$. Klęska sił komunistycznych doprowadziła do uchodźctwa politycznego. Pierwszy etap emigracji w 1948 roku obejmował dzieci z terenów objętych działaniami zbrojnymi, drugi nastąpił już po przegranej wojnie w 1949 roku i dotyczył przede wszystkim dorosłych (z niewielkim udziałem nieletnich) ${ }^{8}$. Ta grupa ludności po 1956 roku również wyjeżdżała, przede wszystkim do Jugosławii, część powróciła do Grecji. Wahaniom podlegała także liczebność grupy Czechów. Wynikało to zarówno z akcji przesiedleń-

5 Zostaną podane dane szacunkowe w wybranych latach.

${ }^{6}$ Dla przykładu: w 1947 r. w woj. wrocławskim było 21 tys. Niemców, taka sama liczba Ukraińców (M. Hejger, Przeksztatcenia narodowościowe na Ziemiach Zachodnich i Pótnocnych Polski w latach 1945-1959, Słupsk 2008, s. 78 i 87); ok. 2300 Czechów (liczba po akcji weryfikacyjnej; ibidem, s. 295). Natomiast w połowie 1946 r. Dolny Śląsk zamieszkiwało ok. 90 tys. Żydów.

7 Wojna domowa trwała w latach 1946-1949 między popierającymi rząd i króla siłami a komunistycznymi bojówkami, zrzeszonymi w oddziały Demokratycznej Armii Grecji. A. Kurpiel, Uchodźcy z greckiej wojny domowej na Dolnym Ślasku - zarys problematyki, [w:] Ziemie Zachodnie - historia i perspektywy, red. W. Kucharski i G. Strauchold, Wrocław 2011, s. 157.

8 W sumie do Polski trafiło około 14 tys. osób, z czego 3934 było niepełnoletnich, I. Kubasiewicz, Dzieci i mtodzież z Grecji w realiach PRL: domy dziecka, szkolnictwo, wychowanie, [w:] PRL a wojna domowa w Grecji, red. M. Semczyszyn, Szczecin 2016, s. 176. 
czej, jak i weryfikacyjnej. Bardziej stabilna była liczba Ukraińców, którzy znaleźli się (wbrew swojej woli) na tzw. Ziemiach Odzyskanych w wyniku akcji „Wisła” w 1947 roku.

Ze względu na „różny” stosunek państwa do poszczególnych mniejszości (wynikający często z uwarunkowań politycznych), odmienne były możliwości pielęgnowania języka (tym samym tworzenia placówek oświatowych) i własnej kultury narodowej w poszczególnych okresach czasu? Najwcześniej zgodę na otwarcie szkół z językiem ojczystym oraz utworzenie instytucji kulturalnych otrzymali Żydzi, najpóźniej - Ukraińcy. Żydzi rozpoczęli organizowanie placówek oświatowych już w 1945 roku, Czesi - w 1947, Niemcy w 1950, a Ukraińcy w 1952 roku. Grekom i Macedończykom państwo polskie starało się zapewnić edukację wkrótce po przyjeździe do Polski.

W polityce narodowościowej PRL można zauważyć momenty przełomowe. Szczególnie po 1956 roku widać większe zainteresowanie i otwartość w stosunku do szkolnictwa mniejszościowego. Podkreślano, że szkoły mniejszościowe „z jednej strony pielęgnują wśród młodzieży ojczystą kulturę narodową i utrzymują żywą łączność ze środowiskiem narodowościowym, a z drugiej strony wiążą tę młodzież z kulturą polską i przygotowują ja do budownictwa socjalizmu w Polsce" ${ }^{10}$. W tym okresie powstaje większość mniejszościowych towarzystw społeczno-kulturalnych, które dużo miejsca w swojej działalności poświęcają problemom oświatowym. Pewne symptomy zmian pojawiły się już jednak wcześniej, kiedy to 31 VIII 1950 roku Ministerstwo Oświaty wydało zarządzenie wewnętrzne nr 28, w którym deklarowano, że każdej grupie narodowej zostanie zapewniona możliwość

${ }^{9}$ W kwestii narodowościowej oficjalnie głoszono zasadę równouprawnienia. W „Wytycznych MAP w sprawie działalności wydziałów i referatów społeczno-politycznych z 22 VIII 1949 roku” stwierdzono: „Odnośnie mniejszości narodowych obowiązuje zasada pełnego poszanowania ich odrębności narodowych, kulturalnych, językowych itp."; L. Olejnik, Polityka narodowościowa Polski w latach 1944-1959, Łódź 2003, s. 45. Zasadę równouprawnienia zakładała także konstytucja PRL. Faktycznie niewiele w obszarze „równouprawnienia” (także tego szkolnego) mniejszości się działo.

${ }^{10}$ Archiwum Akt Nowych (dalej AAN), Ministerstwo Oświaty sygn. 1795, Wnioski Komisji KC PZPR ds. Narodowościowych dotyczące dalszego rozwoju szkolnictwa dla mniejszości narodowych, 28 VIII 1957, s. 12. 
pielęgnowania „własnej kultury socjalistycznej w treści i narodowej w formie"11.

Szkolnictwo mniejszościowe podlegało Ministerstwu Oświaty, Departamentowi Szkół Ogólnokształcących z Niepolskim Językiem Nauczania, który oficjalnie odpowiedzialny był za inicjowanie i prowadzenie wszelkich spraw związanych z rozbudową i funkcjonowaniem szkolnictwa mniejszościowego ${ }^{12}$. W Wydziałach Oświaty Prezydiów Wojewódzkich Rad Narodowych działały natomiast Referaty Szkół z Niepolskim Językiem Nauczania, na czele z okręgowymi wizytatorami, którzy mieli za zadanie czuwać nad całokształtem spraw szkolnictwa mniejszościowego. Z kolei na szczeblu powiatowym nadzór nad szkołami mniejszości mieli podinspektorzy znający język i problematykę konkretnego szkolnictwa narodowego ${ }^{13}$. Po 1956 roku przy Ministerstwie Oświaty powstały sekcje metodyczne dla poszczególnych języków, a przy kuratoriach - ogniska metodyczne ${ }^{14}$. Szkolnictwem mniejszościowym zajmowała się też Komisja Narodowościowa przy KC PZPR. Zdarzało się, że w ramach Ministerstwa powstawały odrębne sekcje, którym przydzielano bardziej szczegółowe działania związane z kwestiami oświatowymi czy bytowymi dla mniejszości (dzieci i młodzieży). Na przełomie października i listopada 1952 roku w Ministerstwie Oświaty powstała „komórka akcji

11 „Zadaniem szkół z niepolskim językiem nauczania jest wychowanie młodzieży $\mathrm{w}$ duchu socjalistycznego internacjonalizmu oraz patriotycznego przywiązania do Polski Ludowej przy uwzględnieniu zarówno w pracy wychowawczej jak i w programie nauki elementów kultury narodowej odpowiednich środowisk", AAN, Ministerstwo Oświaty, sygn. 467, Notatka dla ministra 15 VII 1951, s. 4.

${ }^{12}$ AAN, Ministerstwo Oświaty, sygn. 784, Stosunek PRL do ludności niepolskiej, s. 107 .

13 Archiwum Państwowe we Wrocławiu (dalej AP Wrocław), Prezydium Wojewódzkiej Rady Narodowej (dalej PWRN) we Wrocławiu, Kuratorium Okręgu Szkolnego (dalej KOS), sygn. XVII/92, Instrukcja w sprawie organizacji roku szkolnego 1952/53 w szkołach z niepolskim językiem nauczania, s. 159, 163.

${ }^{14}$ Np. języka żydowskiego, AAN, KC PZPR, Wydział Administracyjny, Komisja Narodowościowa, sygn. 237/XIV/149, O szkolnictwie z żydowskim językiem nauczania, s. 79. 
socjalnej do koordynacji pracy opiekuńczo-wychowawczej nad dziećmi zagranicznymi", m.in. greckimi ${ }^{15}$.

Jak wspomniano, najwcześniej pozwolenie na powołanie własnych szkół otrzymali Żydzi, co wynikało ze stosunku władzy ludowej do tej nacji. Za zgodą i pod egidą władzy od sierpnia 1944 roku na ziemiach polskich zaczęły powstawać Komitety Żydowskie odpowiedzialne za opiekę nad ocalałymi Żydami, ich bezpieczeństwo i wsparcie finansowe, natomiast w listopadzie 1944 roku został utworzony Centralny Komitet Żydów Polskich (CKŻP), jako tymczasowa reprezentacja Żydów polskich ${ }^{16}$. CKŻP w pierwszych miesiącach po wyzwoleniu podjął starania o zorganizowanie szkolnictwa dla dzieci żydowskich. Przy Komitecie powstał Wydział Oświaty, a w wojewódzkich oddziałach CKŻP powoływano referaty szkolne, które miały organizować placówki oświatowe w terenie. Podczas zorganizowanej 17 VI 1945 roku w Dzierżoniowie pierwszej wojewódzkiej konferencji komitetów żydowskich Dolnego Śląska, podjęto uchwałę w sprawie organizowania żydowskich szkół pod egidą CKŻ ${ }^{17}$. Placówki zaczęły powstawać już w 1945 roku, ale nasilenie procesu organizowania szkół nastąpiło w 1946 roku. Przy Wojewódzkim Komitecie Żydowskim we Wrocławiu utworzono Wydział Oświaty, który miał koordynować organizowanie pla-

${ }_{15}$ M. Wojecki, Pobyt i ksztatcenie dzieci uchodźców politycznych z Grecji w państwowych ośrodkach wychowawczych w Polsce po II wojnie światowej, Zielona Góra 2013, s. 33.

${ }^{16}$ Ogólnopolska świecka organizacja, istniejąca od listopada 1944 do 1950 roku (do lutego 1945 roku funkcjonująca pod nazwą Tymczasowy Centralny Komitet Żydów Polskich). Miała stanowić polityczną reprezentację Żydów wobec władz polskich i organizacji żydowskich za granicą, jak też objąć opieką ocalałych Żydów. Zob. H. DatnerŚpiewak, Instytucje opieki nad dzieckiem i szkoty powszechne Centralnego Komitetu Żydów Polskich w latach 1945-1946, „Biuletyn Żydowskiego Instytutu Historycznego w Polsce” 1981, nr 3, s. 38 oraz M. Borkowski, A. Kirmiel, T. Włodarczyk, Śladami Żydów. Dolny Ślask. Opolszczyzna. Ziemia Lubuska, Warszawa 2008, s. 146. Po 1950 r. kompetencje CKŻP przejęło TSKŻ.

17 J. Dudek, Szkolnictwo średnie ogólnoksztatcące dla mniejszości narodowych na Dolnym Ślasku, „Śląski Kwartalnik Historyczny Sobótka” 1971, R. 26, nr 1, s. 83; H. Datner-Śpiewak, Instytucje opieki nad dzieckiem i szkoty powszechne Centralnego Komitetu Żyów w Polskich w latach 1945-1946, „Biuletyn Żydowskiego Instytutu Historycznego w Polsce" 1981, nr 3, s. 37-51. O korespondencji CKŻP z MO i wspomnianych etapach: H. Datner, Szkoty Centralnego Komitetu Żdów w Polsce w latach 1944-1949, „Biuletyn Żydowskiego Instytutu Historycznego w Polsce” 1994, nr 103, s. 104-119. 
cówek i uregulować stan prawny oraz - co się z tym wiąże - także zasady finansowania. Istotne było również to, jaki język wykładowy będzie obowiązywał w żydowskich szkołach.

W maju 1946 roku związek żydowski województwa wrocławskiego zwrócił się do kuratorium z prośbą o zezwolenie na otwarcie $\mathrm{w}$ dziesięciu powiatach żydowskich szkół powszechnych opłacanych przez żydowski fundusz społeczny ${ }^{18}$. Pismo zapoczątkowało korespondencję pomiędzy Kuratorium Okręgu Szkolnego Wrocławskiego a Ministerstwem Oświaty i Biurem Ziem Odzyskanych, która miała doprowadzić do „wydania zasadniczego poglądu w tej sprawie" i ułatwić kuratorium podjęcie stosownych decyzji. Mimo że status ludności żydowskiej w Polsce wydawał się uregulowany i Żydzi cieszyli się sympatią władz, przekonania o konieczności istnienia odrębnych placówek żydowskich nie było. Opinia wydana przez Ministerstwo sugerowała ostrożność w tworzeniu żydowskich placówek oświatowych oraz wskazywała problemy i obawy związane z ich organizacją:

Wydaje się, że należy unikać ponownego tworzenia getta żydowskiego pod jakimikolwiek powodami. Z drugiej strony nie możemy odmawiać komukolwiek prawa do nauczania dzieci w ich języku ojczystym. Pragnąc pogodzić i interes dziecka żydowskiego i interes państwa, który upatruje w jednakowych dla wszystkich dzieci warunkach szkolnych $\mathrm{w}$ asymilacji kulturowej ze środowiskiem, jednak i bez jakichkolwiek form administracyjnego nacisku czy nacjonalistycznych szykan ${ }^{19}$.

Zaproponowano w związku z tym wyrażenie zgody na zakładanie szkół o charakterze prywatnym, „w ośrodkach największego zagęszczenia środowiska żydowskiego" ${ }^{20}$. Zasugerowano także, aby władze szkolne pod-

${ }^{18}$ AAN, Ministerstwo Oświaty, sygn. 473, Pismo Kuratorium Okręgu Szkolnego Wrocławskiego z dnia 25 maja 1946 roku do Ministerstwa Oświaty w Warszawie (nr I-7901/46), s. 1.

19 Ibidem, s. 2.

${ }^{20} \mathrm{~W}$ piśmie zastępcy Biura Ziem Odzyskanych do Kuratorium Okręgu Szkolnego Wrocławskiego odnośnie zakładania szkół prywatnych jest sugestia, że mogą powstawać takowe, ale założyciele tych szkół mają otrzymać zezwolenie kuratorium na ich prowadzenie, o ile będą spełniać wymogi określone ustawą o prywatnych szkołach oraz zakładach naukowych i wychowawczych z 11 III 1932 r. (Dz.U. RP nr 33 poz. 343) i rozporządze- 
jęły akcję propagandową, która będzie miała na celu uświadomienie, że polska publiczna szkoła może zapewnić żydowskiemu dziecku właściwe warunki „spokojnego życia i pracy”21. Biuro Ziem Odzyskanych zwracało też uwagę na konieczność dopracowania kwestii programów, podręczników, określenia nadzoru, ustalenia języka urzędowego, np. druków szkolnych czy rozstrzygnięcia problemu wolnych sobót, spowodowanego względami wyznaniowymi. Odniosło się również do obaw, że fundusze na utrzymanie szkół będą "płynęły” z zagranicy, więc „sprawy dotyczące szkół żydowskich w Polsce niewątpliwie odbiją się prędzej czy później na terenie międzynarodowym..."22.

W marcu 1946 roku Referat Szkolny CKŻP zlecił ujednolicenie programów w swoich szkołach, a we wrześniu konferencja nauczycieli szkół żydowskich obradująca w Łodzi stwierdziła, że „szkoła żydowska ma za zadanie wychowanie młodego pokolenia żydowskiego zgodnie ze współczesnymi postępowo-społecznymi ideami”. Domagano się także stosowania języka żydowskiego ${ }^{23}$ jako wykładowego i szerokiego uwzględnienia języka polskiego i hebrajskiego ${ }^{24}$. W pierwszym latach szkoły działały więc jako placówki prywatne pod egidą CKŻP. Podejmowane jednak przez władze

nia wykonawczego do tej ustawy z 7 VI 1932 roku (Dz.U. RP nr 50 poz. 473), AAN, Ministerstwo Oświaty, sygn. 473 (pismo BZO 116/46), s. 6.

${ }^{21}$ Ibidem, s. 1.

22 AAN, Ministerstwo Oświaty, sygn. 473, Pod pismem podpisał się L. Eckert - ministerialny wizytator szkół, zastępca dyrektora BZO, s. 6-7.

${ }^{23}$ Po II wojnie światowej na terenie Polski, zarówno w dokumentacji szkolnej, jak i oficjalnych pismach (np. ministerialnych) używano określenia język żydowski, a nie terminu jidysz. W obu przypadkach chodzi o ten sam język „mieszany”, którego ukształtowanie się jest efektem przyjmowania przez Żydów języka kraju, w którym zamieszkują. Jidysz powstał bowiem z połączenia hebrajskiego (który dostarczył mu alfabetu oraz terminologii religijnej i prawniczej), niemieckiego - odpowiedzialnego za większą część słownictwa i jego odmiany (fleksję) oraz kilku języków słowiańskich (w tym polskiego), tworzących charakterystyczny szkielet gramatyczny, głównie składniowy. $\mathrm{O}$ „zawiłościach” języków żydowskich: E. Geller, Kraina języka jidysz [online], dostępny na: www.jidyszland.pl/index_. php?d=75 [dostęp: 12 IX 2016].

${ }^{24}$ Język hebrajski, czyli najstarszy z języków żydowskich, w którym spisana został Biblia. Został wskrzeszony w XIX w., a obecnie jest oficjalnym językiem Państwa Izrael. Zob. M. Borkowski, A. Kirmiel, T. Włodarczyk, Śladami Żydów. Dolny Śląsk. Opolszczyzna. Ziemia Lubuska, Warszawa 2008, s.147. 
organizacji starania o ich upaństwowienie znajdą zrozumienie w kolejnych latach i od roku szkolnego 1949/1950 staną się placówkami publicznymi (te, które uzyskają pozytywną rekomendacje władz lokalnych opartą na odbytych wcześniej wizytacjach ${ }^{25}$. Na początku 1949 roku we wszystkich dolnośląskich szkołach żydowskich przeprowadzona został wizytacja Inspektoratu Szkolnego, mająca ustalić, która z placówek spełnia wymogi „szkoły państwowej” i może dostać miano publicznej ${ }^{26}$.

Przez cały okres istnienia szkół żydowskich na ich stan liczbowy wpływ miały wyjazdy Żydów. Stąd liczba uczniów czasami zmieniała się kilka razy w ciągu roku. Większe fale migracyjne miały miejsce na przełomie lat czterdziestych i pięćdziesiątych oraz w latach 1956-1960. Po tej drugiej fali na Dolnym Śląsku pozostały tylko szkoły w Bielawie, Dzierżoniowie, Legnicy, Wałbrzychu, Wrocławiu (i to też tylko chwilowo, ponieważ zasilili je repatrianci z ZSRR). Kres istnienia placówek żydowskich przyniósł rok 1968. Po wydarzeniach marcowych władze nie widziały dalszego sensu utrzymywania szkół żydowskich, które i tak były już tylko kilkuosobowymi zespołami. Następowało ich „wygaszanie”, poprzez umożliwienie młodzieży dokończenia edukacji (jak w liceum wrocławskim), lub likwidacja i konieczność przejścia do placówek polskich.

W szkołach podlegających CKŻP obowiązywał program szkoły powszechnej uzupełniony o przedmioty dodatkowe. Językiem wykładowym

25 W kwietniu 1948 r. Ministerstwo zwracało uwagę, że jest skłonne upaństwowić większe szkoły żydowskie. Nie widzi sensu utrzymywania szkół poniżej 20 dzieci, w związku z czym proponuje się, aby uczniowie przeszli do polskich szkół publicznych a język żydowski czy kulturę żydowską poznawały w świetlicach żydowskich czy na dodatkowo organizowanych zajęciach. AP Wrocław, KOS, sygn. 696, [Pismo Ministerstwa Oświaty do Kuratorium Okręgu Szkolnego z kwietnia 1948], s. 46.

${ }^{26}$ W kwietniu 1949 r. ukazuje się oficjalne zarządzenie ministra w sprawie otwarcia 18 szkół publicznych (względnie państwowych) z żydowskim językiem nauczania. Otwarcie oznaczało upublicznienie szkół już istniejących i funkcjonujących pod auspicjami Centralnego Komitetu Żydów. AAN, Ministerstwo Oświaty, sygn. 467, Szkolnictwo z niepolskim językiem nauczania w Polsce Ludowej - notatka dla ministerstwa, s. 1-4. Oficjalne Zarządzenie Ministra Oświaty w sprawie programu nauki oraz języka urzędowego w szkołach ogólnokształcących z niepolskim językiem nauczania, ukazało się 20 VIII 1952 r. AP Wrocław, oddział w Legnicy (dalej AP Legnica), PPRN w Legnicy, sygn. 475, s. 1-2. 
miał być język jidysz, dodatkowo nauczany był hebrajski oraz historia Żydów. Dla przykładu - w Szkole Podstawowej nr 7 w Legnicy z żydowskim językiem nauczania, w klasach od I do III było po sześć godzin języka polskiego i żydowskiego. Od IV do VI pozostało 6 godzin polskiego, a żydowskiego było godzinę mniej. W trzeciej klasie wprowadzano język hebrajski w wymiarze 4 godzin. A w kolejnych trzech latach były po trzy godziny tego języka. Od IV klasy w planie pojawiała się też historia Żydów w wymiarze dwóch godzin tygodniowo.

W pierwszym okresie funkcjonowania szkół żydowskich na Dolnym Śląsku widać było stały wzrost liczebności tych placówek. W czerwcu 1946 roku istniało 16 szkół z 1280 dziećmi (Legnica, Wrocław, Dzierżoniów, Kłodzko, Świdnica, Ziębice, Chojnów, Ząbkowice, Bielawa, Wałbrzych, Jawor, Strzegom, Duszniki, Nowa Ruda, Złotoryja, Puszczykowo). W lipcu zorganizowano kolejne trzy: w Bystrzycy, Bielawie i Przemkowie (choć ta ostatnia, ze względu na brak nauczyciela, wkrótce przestała istnieć). A w sierpniu było już 21 placówek uczących 1266 uczniów. Pod koniec 1946 roku ich liczba wzrosła do 23 z 1664 uczniami. W 1947 roku we Wrocławiu zorganizowano gimnazjum żydowskie (przekształcone później w liceum), jak też działały szkoły artystyczne: muzyczna, plastyczna oraz baletowa. Obok szkół finansowanych przez CKŻP powstawały również szkoły hebrajskie, prowadzone przez Hechaluc Pionier ${ }^{27}$, oraz wyznaniowe pod opieką Kongregacji. Były to jednak placówki mniej liczne i nie cieszące się ani poparciem kuratorium (większość z nich zresztą nie zabiegała o uznanie władz oświatowych), ani CKŻP. Komitet uważał, że jest to niepotrzebna konkurencja osłabiająca podległe mu, dobrze działające szkoły, która nie powinna pojawiać się tam, gdzie funkcjonowały „komitetowe” placówki oświatowe ${ }^{28}$. Natomiast wobec zwizytowanych przez kuratoria lub lokalne władze oświatowe placówek hebrajskich, wysunięto zarzuty, że plan wychowawczy jest realizowany „w duchu wybitnie nacjonalistycz-

27 W 1947 r. tych szkół na Dolnym Śląsku było 6 (w Dzierżoniowie, Wałbrzychu, Legnicy, Wrocławiu, Bielawie, Świdnicy).

${ }^{28}$ AP Wrocław, Wojewódzki Komitet Żydowski, sygn. 5, s. 106. Należy pamiętać, że spór o szkoły był też konfliktem między syjonistami a przedstawicielami partii lewicowych (Frakcja PPR, Bund). 
nym”, że udostępniono puszki na fundusz palestyński, że przygotowują one młodzież jedynie do emigracji, a z punktu dydaktycznego niewiele są w stanie nauczyć, ponieważ pracujący w nich nauczyciele nie mają kwalifikacji (a czasami nawet nie znają języka hebrajskiego, który stanowi podstawę nauczania w tych szkołach) ${ }^{29}$. Z kolei placówki wyznaniowe (chedery) trudno było do końca traktować jako szkoły. Uczęszczały do nich dzieci w wieku od 6-10 lat, często dodatkowo chodzące do szkół prowadzonych przez komitety żydowskie lub hebrajskich. Faktycznie zajęcia opierały się o czytanie Biblii, ksiąg religijnych oraz poznawanie modlitw. We Wrocławiu funkcjonował także jeszybot.

Od 1948 roku, po pojawieniu się konkretnych planów upaństwowienia szkół, doszło do zmniejszenia ich liczby, ponieważ nie wszystkie placówki zostały pozytywnie zaopiniowane. Już w 1948 roku zlikwidowano szkoły w Złotoryi, Lubawce i Bolkowie. Od roku szkolnego 1949/1950 przestały też istnieć na Dolnym Śląsku szkoły hebrajskie. Od tego momentu można też mówić o podporządkowaniu szkół państwu, a nie instytucjom żydowskim, co oznaczało utratę autonomii. W 1949 roku na Dolnym Śląsku zostało 12 szkół, w których 87 nauczycieli uczyło 1740 dzieci ${ }^{30}$. Po upaństwowieniu Ministerstwo zezwoliło na zakładanie szkół podstawowych w obwodach, w których przebywało co najmniej 25 dzieci w wieku szkolnym i na uruchomienie klas licealnych przy liczbie 15 uczniów ${ }^{31}$. Program szkół żydowskich został zmodyfikowany, tak, że stał się porównywalny z obowiązującym w szkolnictwie polskim. Język polski wprowadzano od II klasy, język żydowski od I, historię Żydów od klasy IV a język hebrajski od $\mathrm{V}^{32}$. Rozporządzenie Ministerstwa regulowało też kwestie podręczników, zatrudniania nauczycieli, jak również sprawy związane z administracją szkół. W roku szkolnym 1950/51 na Dolnym Śląsku zostało już tylko 8 placówek. Kolejne lata przyniosły likwidację szkół w Świdnicy, Ziębicach i Pieszycach. Tam, gdzie zamykano żydowskie placówki stara-

${ }^{29}$ AP Wrocław, KOS, sygn. 77, Sprawozdania z wizytacji szkół hebrajskich, s. 70.

${ }^{30}$ AŻIH, TSKŻ, sygn. 853, Sprawozdanie Wydziału Oświaty za okres od 1 I do 1 VIII 1950 r., bp.

${ }^{31}$ Dziennik Urzędowy Ministerstwa Oświaty, 1949, nr 9, poz. 163

32 Ibidem. 
no się prowadzić dodatkową naukę języka jidysz w ramach kompletów, w szkołach polskich. Nauczanie języka proponowały też kluby Towarzystwa Społeczno-Kulturalnego Żydów w Polsce (TSKŻ). Kursy jidysz i języka polskiego prowadzone przez oddziały TSKŻ okazały się niezbędne w czasach repatriacji z ZSRR ${ }^{33}$. W tym okresie na krótko wzrosła liczba uczniów szkół żydowskich, a nawet Ministerstwo Oświaty i kuratorium wrocławskie wydało zgodę na otwarcie drugiego (obok Wrocławia) liceum żydowskiego w Legnicy ${ }^{34}$. W roku szkolnym 1961/62 istniały już tylko szkoły we Wrocławiu, Legnicy, Wałbrzychu i Dzierżoniowie. Systematycznie spadała jednak liczba uczniów. W przypadku szkół podstawowych w Dzierżoniowie i Wałbrzychu już w 1962 roku zastanawiano się nad ich likwidacją, pojawił się też pomysł łączenia klas żydowskich i polskich w liceach. W Legnicy w szkole żydowskiej uczyły się też dzieci greckie i macedońskie, podobnie jak w Wałbrzychu. W 1964 roku zlikwidowano szkołę w Dzierżoniowie. W roku szkolnym 1967/68 oficjalnie działały szkoły w Legnicy, Wrocławiu i Wałbrzychu, ale praktycznie do każdej z nich dokładano klasy polskie. Szkoły te zamknięto w 1969 roku.

W przypadku ludności czeskiej impulsem do utworzenia placówek oświatowych stał się układ o wzajemnej pomocy i przyjaźni z 10 III 1947 roku zawarty między Polską a Czechosłowacją pod naciskiem ZSRR, który miał pomóc w rozwiązaniu sporów granicznych, jak też w uregulowaniu statusu Polaków w Czechosłowacji oraz Czechów i Słowaków w Polsce ${ }^{35}$. Porozumienie pomogło również przeprowadzić weryfikację narodową na spornych terenach ${ }^{36}$. Po zakończeniu akcji weryfikacyjnej

${ }^{33}$ AP Wrocław, KW PZPR, 74/IV/76, Egzekutywa, s. 230.

${ }^{34}$ AAN, Ministerstwo Oświaty, sygn. 1759, s. 76, 78.

$35 \mathrm{~W}$ protokole-załączniku do tego układu strony zobowiązały się, że „zapewnią Polakom w Czechosłowacji oraz Czechom i Słowakom w Polsce w ramach praworządności i na zasadzie wzajemności możliwości rozwoju narodowego, politycznego, kulturalnego i gospodarczego (szkoły, stowarzyszenia, spółdzielnie na zasadzie jedności spółdzielczości w Polsce względnie Czechosłowacji. D..U. RP, 1948, nr 7, poz. 47).

${ }^{36}$ Zanim doszło do zawarcia układu, strona czeska bardzo liberalnie „weryfikowała” mieszkańców powiatów strzelińskiego, kłodzkiego, jeleniogórskiego (czyli obszarów spornych z Polską). Do wydania zaświadczenia o posiadaniu narodowości czeskiej wystarczyła deklaracja zainteresowanego. Inna rzecz, że strona polska w większości dotychczasowych mieszkańców widziała Niemców (zwłaszcza, że przypadki deklarowania narodowości cze- 
województwo wrocławskie zamieszkiwało 2343 Czechów ${ }^{37}$. Po „odwilży” 1956 roku większość z nich wyemigrowała do Czechosłowacji i Niemiec.

Tuż po podpisaniu porozumienia polsko-czechosłowackiego w Ministerstwie Oświaty w Departamencie II powołano Referat Czechosłowacki z wizytatorem Stefanem Bąkowskim na czele, który miał odpowiadać za zorganizowanie placówek z językiem czeskim. Ministerstwo wystąpiło do Kuratorium Okręgu Szkolnego (KOS) wrocławskiego o otwarcie takich szkół ${ }^{38}$. Wrocławskie kuratorium poleciło inspektoratom szkolnym w terenie podjęcie konkretnych działań w celu utworzenia placówek. W efekcie powstały dwie szkoły - jedna w Kudowie, druga w Gościęcicach Średnich w powiecie strzelińskim. Inauguracja placówki w Kudowie Zdroju nastąpiła 10 IX 1947 roku zaś szkoła w Gościęcicach rozpoczęła działalność 10 I 1949 roku i uczyło się w niej początkowo 97 dzieci. W pierwszym roku szkolnym kudowska placówka miała natomiast 192 uczniów ${ }^{39}$. Z zachowanej dokumentacji wynika jednak, że ze względu na przedłużający się remont budynku, w pierwszych tygodniach był problem z prowadzeniem zajęć lekcyjnych ${ }^{40}$. Oprócz uczniów z Kudowy do placówki tej uczęszczały również dzieci z okolicznych miejscowości. Prawo do pobierania nauki miały osoby, które zostały zweryfikowane jako Czesi. Nauczycielami byli Polacy (3 osoby edukowały czeskie dzieci) znający biegle język czeski ${ }^{41}$. W dokumentach pojawiają się także nazwiska nauczycieli Czechów, możliwe więc, że czasowo i oni zasilali kadrę placówek. Nie ma informacji na temat ich kwalifikacji, ale można przypuszczać, że - podobnie jak w przypadku pozostałych szkół mniejszościowych - nie były one odpowiednie.

skiej przez Niemców i tym samym unikania wysiedlenia zdarzały się dosyć często). Zob. M. Hejger, op. cit., s. 304.

${ }^{37}$ Ibidem, s. 306.

38 AAN, Ministerstwo Oświaty, sygn. 469, Pismo Ministerstwa Oświaty do KOS wrocławskiego z 16 V 1947 r., s. 176.

39 Statystyki zmieniały się, ponieważ już na początku 1948 r. było tych uczniów 162 . Ibidem, s. 179.

40 AP Wrocław, oddział w Kamieńcu Ząbkowickim, Inspektorat Szkolny w Kłodzku, sygn. 70, Pismo Inspektoratu Szkolnego w Kłodzku do KOS we Wrocławiu z 14 X 1947 r., s. 15 .

${ }^{41}$ Tak zakładało ministerstwo. 
Kudowska szkoła rozpoczynała swoją działalność jako szkoła sześcioklasowa. W roku szkolnym 1949/1950 było już siedem klas (153 uczniów). Język czeski nauczany był w wymiarze 4 godzin tygodniowo, a polski 5 . W klasach V-VII dochodziły 2 godziny języka rosyjskiego. Nauczano także historii i geografii Czechosłowacji. W roku szkolnym 1950/51 w dwóch szkołach języka czeskiego uczyły się 202 osoby pod kierunkiem 5 nauczycieli. W kolejnym roku liczba uczniów zmalała do 181. Kres szkołom czeskim położyło powstanie szkół niemieckich. W lutym 1952 roku znaczna część rodziców dzieci uczęszczających do kudowskiej szkoły zgłosiła potrzebę uruchomienia szkoły z niemieckim językiem nauczania ${ }^{42}$. Rok szkolny 1952/53 był ostatnim rokiem funkcjonowania placówki w Kudowie, a budynek szkoły został przekazany placówce niemieckiej. Druga szkoła działała do 1962 roku. W ostatnim roku istnienia uczyło się w niej 9 osób ${ }^{43}$.

Decyzja o przyjeździe Greków i Macedończyków do Polski zapadła w Moskwie i była warunkowana chęcią pomocy „bratnim” komunistom. Przybysze mieli więc pełne poparcie władz państwowych i partyjnych, dlatego nie było ograniczeń w zakresie posługiwania się językiem ojczystym, bardzo szybko podjęto też starania o organizację edukacji w języku narodowym ${ }^{44}$. W latach 1948-1960 w Polsce znalazło się ponad 14 tys. Greków i Macedończyków ${ }^{45}$. Akcja łączenia rodzin, jak też emigracja do Bułgarii, Jugosławii oraz reemigracja do Grecji, spowodowała jednak, że w połowie lat siedemdziesiątych mniejszość grecka liczyła niecałe 8 tys. osób. Emigrantów umieszczano w specjalnych ośrodkach (tajnych,

42 AP Wrocław, PWRN KOS, sygn. XVII/92, s. 125, Pismo z 12 II 1952. Powodem miał być fakt nieuzyskania przez rodziny obywatelstwa czeskiego. Choć pewnie była to kwestia „niezdecydowania co do przynależności narodowej”, może też koniunktury.

43 AP Wrocław, PWRN KOS, sygn. XVII/92, Wykaz szkół z czeskim językiem nauczania stan na dzień 24 X 1952 r., s. 146a.

$44 \mathrm{~W}$ pierwszych latach pobytu raczej nie można nazwać ich mniejszością narodową; byli raczej uchodźcami politycznymi.

45 W tym blisko 4000 dzieci. We wrześniu i październiku 1948 r. przyjechało nieletnich 1013; kolejne 2092 w kwietniu 1949 r. a w październiku 1949 r. 400 dzieci. I. Kubasiewicz, Emigranci z Grecji w Polsce Ludowej. Wybrane aspekty z życia mniejszości [online], dostępny na: http://polska1918-89.pl/pdf/emigranci-z-grecji-w-polsce-ludowej.wybrane-aspekty-z-zycia-mniejszos,4586.pdf [dostęp 12 IX 2016], s. 2; M. Wojecki, op. cit., s. 10. 
zamkniętych, których personel zobowiązany był nie ujawniać żadnych informacji na ich temat). W związku z tym, że pobyt emigrantów utrzymywany był w tajemnicy, również akty prawne czy „wytyczne” dotyczące nauczania były opatrywane klauzulami „tajne”, „poufne”46. Pierwsza grupa dzieci została umieszczona $\mathrm{w}$ Lądku Zdroju, kolejne w innych miejscowościach Dolnego Śląska: Bardzie, Międzygórzu, Płakowicach (w pobliżu Lwówka Śląskiego), Solicach Zdroju (obecnie Szczawno Zdrój) ${ }^{47}$. W sumie w tamtejszych ośrodkach w latach 1948-1950 przebywało 3113 dzieci między 3 a 18 rokiem życia. Ponadto ponad 700 dzieci znajdowało się na utrzymaniu rodziców i mieszkało przede wszystkim w Legnicy i Zgorzelcu. Pod koniec 1949 roku dzieci greckie i macedońskie przeniesiono z domów wypoczynkowych do utworzonego dla nich Państwowego Ośrodka Wychowawczego (POW) w Zgorzelcu, natomiast w sierpniu 1951 roku utworzono nowy POW w Policach, do którego skierowano część dzieci, pozostałe „rozdzielono” po polskich domach dziecka na terenie Dolnego Śląska. Tam też działał POW w Płakowicach, w którym funkcjonowała jedna szkoła podstawowa dla dzieci greckich ${ }^{48}$. W szkole było 10 klas greckich i 11 macedońskich ${ }^{49}$. Część dzieci nadal mieszkała z rodzicami, a po akcji łączenia rodzin w połowie lat pięćdziesiątych XX wieku liczba ta wzrosła. Rodziny greckie stopniowo rozsiedlano po Polsce (znaczna część znalazła się na Dolnym Śląsku, oprócz Zgorzelca także w: Legnicy, Jeleniej Górze, Bielawie, Dzierżoniowie, Lubaniu, Niemczy, Świdnicy, Wałbrzychu i Wrocławiu).

Jednym z ważniejszych celów działania ośrodków wychowawczych było umożliwienie wszystkim wychowankom w wieku szkolnym wypełnie-

46 Takimi opatrzone były „Wytyczne do przygotowania siatki godzin na rok 1952/53 dla szkół ogólnokształcących POW” w Policach koło Szczecina. Macedońscy uchodźcy w Polsce. Zagadnienia wychowania i ksztatcenia dzieci i mtodzieży, dokumenty 1948-1975, wybór, przekład, wstęp i redakcja P. Nakovski, Skopje 2008, t. 1, s. 356-357.

${ }^{47}$ Były to przede wszystkim miejscowości wypoczynkowe. Dzieci umieszczano w domach wczasowych, z których tworzono placówki opiekuńczo-wychowawcze (tzw. Ośrodki Wychowawcze czy, później, Państwowe Ośrodki Wychowawcze).

${ }^{48}$ M. Wojecki, op. cit., s. 7.

49 W Płakowicach ulokowano w sumie 533 dzieci. I. Kubasiewicz, Dzieci i mtodzież..., s. 176-185. 
nia obowiązku szkolnego oraz zapewnienia młodocianym przygotowania do określonego zawodu i samodzielnego życia ${ }^{50}$. Już w ośrodku w Lądku starano się zorganizować edukację i umożliwić zdobywanie zawodu ${ }^{51}$. Szkołę współtworzył niejaki inspektor Roumeletis, całe kierownictwo było greckie, a personel składał się z 20 nauczycieli. Trudno mówić o jasno zakreślonym programie i zasadach nauczania ${ }^{52}$. Dzieciom starano się przede wszystkim przekazać informacje $\mathrm{z}$ historii, geografii, folkloru Grecji i języka ojczystego. Ogromnym problemem utrudniającym edukację było to, że znaczna część dzieci greckich i macedońskich była niepiśmienna. Ponadto nie było podręczników do nauczania, a większość „nauczycieli” nie miała żadnego przygotowania pedagogicznego. Także w Szczawnie prowadzono ograniczone nauczanie nieprzekraczające 12 godzin tygodniowo. W Lądku nie funkcjonowała szkoła zawodowa, ale w działających warsztatach uczono zawodu krawca, szewca, fryzjera, stolarza. W POW w Zgorzelcu ponad $62 \%$ wychowanków uczyło się w trzech szkołach podstawowych (w sumie 57 oddziałów od I do VII klasy) ${ }^{53}$.

Tam, gdzie znajdowały się większe skupiska rodzin greckich i macedońskich tworzono przy polskich szkołach klasy z greckim i macedońskim językiem nauczania. Od pierwszej klasy językiem podstawowym był grecki lub macedoński. Od drugiej klasy wprowadzano nauczanie języka polskiego. Od trzeciej klasy greckie dzieci uczyły się wspólnie z polskimi, z tym że miały lekcje języka narodowego w wymiarze od 4 do 6 godzin tygodniowo. Kiedy grupy greckie i macedońskie były nieliczne (4-5 dzieci), wówczas tworzono dla nich komplety i nauczano języka greckiego lub

${ }^{50}$ M. Wojecki, op. cit., s. 7

51 Sprawozdanie ogólne z działalności Ośrodka Wychowawczego w Lądku Zdroju za czas od dn. 15 X 1948 do dn. 30 VII 1949, [w:] Macedonscy uchodźcy..., t. 1, s. 350.

52 Te zostały opracowane znacznie później i dotyczyły już nauczania w szkołach poza POW. W Zarządzeniu Ministra Oświaty z 31 V 1957 nr SO-4-2164/57 dzieci miały uczyć się od II klasy greckiego lub macedońskiego 3 godziny w tygodniu; od V klasy wchodził język grecki dla Macedończyków. Można było prowadzić nauczanie w kompletach (dla „sąsiadujących klas”); „Wytyczne w sprawie organizacji nauczania w języku greckimi i macedońskim w szkołach ogólnokształcących i liceach pedagogicznych”, cyt. za: M. Wojecki, op. cit., s. 31 .

53 Ibidem, s. 15. 
macedońskiego w wymiarze 3-4 godzin tygodniowo. W szkołach średnich, do których uczęszczali emigranci, organizowano komplety językowe w wymiarze 2 godzin tygodniowo ${ }^{54}$. We wrześniu 1952 roku w PRL-u było 2649 uczniów greckich i macedońskich ${ }^{55}$. W 1961 roku języka greckiego uczyło się 1148 dzieci w 59 placówkach, a macedońskiego 588 uczniów w 38 szkołach podstawowych i ponadpodstawowych. W 15 placówkach oświatowych działały I i II klasy z językiem greckim i macedońskim dla około 600 uczniów. Pięć lat później języka greckiego uczyło się 1238 dzieci, a macedońskiego tylko 75 . W 1975 roku działało 41 szkół, w których były klasy macedońskie i greckie z 35 nauczycielami. Uczyło się w nich około 2100 osób. Z danych dolnośląskich wiadomo, że w roku szkolnym 1964/65 w 15 miejscowościach istniało 68 kompletów dla 1090 uczniów, w tym 1004 uczniów narodowości greckiej i 86 narodowości macedońskiej. Uczyło w nich 14 nauczycieli kwalifikowanych i jedenaścioro społecznych, przeszkolonych na kursach Ministerstwa Oświaty. Zmniejszyła się przy tym liczba godzin nauczania języka ojczystego na dodatkowych zajęciach. Dzieci w szkołach podstawowych miały zajęcia dwa razy w tygodniu, a młodzież szkół ponadpodstawowych, studiujący czy pracujący mieli lekcje raz w tygodniu. $\mathrm{Na}$ terenie Dolnego Śląska takie zajęcia odbywały się we Wrocławiu (dwie szkoły Towarzystwa Przyjaciół Dzieci przy ulicy Trzebnickiej 42 i Rosenbergów 15), Legnicy (SP nr 11), Chojnowie, Pieńsku, Zgorzelcu (nr 5), Dzierżoniowie (SP nr 4), Świebodzicach, Głuszycy, Lubaniu (SP nr 5), Wałbrzychu, Świdnicy (SP nr 5), Jeleniej Górze (9 i 10) ${ }^{56}$. Absolwentów szkół podstawowych, którzy opanowali dobrze język polski, kierowano do polskich szkół średnich i zawodowych. Młodzi Grecy spośród szkół ponadpodstawowych na Dolnym Śląsku najczęściej wybierali: Technikum Mechaniczno-Radiotechniczne w Dzierżoniowie, Technikum Mechaniczno-Energetyczne we Wrocławiu, państwowe Gimnazjum Mechaniczne w Praczach Odrzańskich ${ }^{57}$. Wielu

${ }^{54}$ Notatka informacyjna o nauczaniu dodatkowym języka greckiego i macedońskiego w szkołach ogólnokształcących i zawodowych na terenie województwa wrocławskiego. Macedońscy uchodźcy..., t. 2, s. 62.

55 I. Kubasiewicz, Dzieci i mtodzież..., s. 185.

56 Dane za: M. Wojecki, op. cit., s. 22.

57 Dane za: ibidem, s. 26. 
Greków zdobywało też wykształcenie w Ośrodku Szkolenia Zawodowego w Wojanowie oraz w Szkole Zawodowej w Legnicy ${ }^{58}$. Wielu absolwentów szkół ponadpodstawowych podejmowało studia na polskich uczelniach. Ułatwieniem w zdobyciu wyższego wykształcenia dla młodych Greków było to, że do 1956 roku nie musieli zdawać egzaminu wstępnego na studia; co prawda od 1957 roku podlegali już tej zasadzie rekrutacyjnej, ale wystarczyło, że uzyskali z egzaminu ocenę dostateczną.

Niemcy uzyskali możliwość organizowania własnych szkół w 1950 roku. Zawarcie 6 VII 1950 roku układu w Zgorzelcu między Polską a Niemiecką Republiką Demokratyczną pozwoliło na "zauważenie” ponad 60 tys. Niemców nadal mieszkających w Polsce i miało wpływ na decyzję o zorganizowaniu dla nich oświaty w języku narodowym. Wcześniej sytuacja polityczna uniemożliwiała powstanie placówek z niemieckim językiem nauczania. Przeciwdziałając ewentualnym próbom nielegalnego funkcjonowania szkół, Ministerstwo Ziem Odzyskanych 14 III 1946 roku wydało zarządzenie o przymusowym wysiedleniu, które w pierwszej kolejności miało objąć pedagogów, którym zakazano jednocześnie prowadzenia działalności zawodowej ${ }^{59}$. Czasami jednak dawni nauczyciele nie zważali na zakaz, zdarzało się też, że „tajnego nauczania” podejmowały się osoby bez kwalifikacji pedagogicznych, ale znające język niemiecki. Dzieci niemieckie korzystały więc z półlegalnego nauczania prowadzanego przez związki wyznaniowe lub osoby prywatne. Wiadomo, że w latach 1945-1946 na Dolnym Śląsku istniały szkoły niemieckie w: Głogowie, Lwówku Śląskim, Oławie, Wrocławiu, natomiast w Wałbrzychu, Polanicy Zdroju, Wrocławiu, Kłodzku prowadzone były komplety. Władze miały świadomość tego, że wbrew zakazowi szkoły funkcjonują, ale reagowały jedynie $\mathrm{z}$ istotnych powodów. Jednym z takich powodów była dostrzegana przez lokalną administrację kwestia prowadzenia zajęć przez przedwojennych nauczycieli-członków NSDAP i na podstawie „hitlerowskich” podręczników. W obliczu takiej sytuacji kuratorium wrocławskie jeszcze przed 1950 rokiem planowało zorganizowanie kompletów dla Niemców, aby objąć oficjalną kontrolą

58 AAN, KC PZPR, sygn. 237/XXII-422, Pismo Ministerstwa Oświaty do Państwowej Komisji Planowania Gospodarczego, k. 51.

${ }^{59}$ M. Hejger, op. cit., s. 86. 
wspomniany proceder, nie spotkało się to jednak z uznaniem władz centralnych $^{60}$. Do 1950 roku dzieci niemieckie teoretycznie mogły uczęszczać do szkół polskich (dzieci pracowników z zielonymi kartami reklamacyjnymi ${ }^{61}$ oraz tych, którzy uzyskali obywatelstwo polskie). Zdarzało się jednak, że kierownicy szkół nie przyjmowali młodych Niemców, obawiając się, że pozytywna decyzja może zostać źle przyjęta przez władze ${ }^{62}$. Ponadto dla dzieci niemieckich barierę w polskich szkołach stanowił język. Zdarzało się też, że dochodziło do konfliktów pomiędzy dziećmi polskimi i niemieckimi wynikających z wojennej traumy. Nauczanie w języku niemieckim odbywało się również w majątkach radzieckich. $\mathrm{O}$ „nieoficjalnym” funkcjonowaniu szkół dla dzieci obywateli niemieckich, pracujących dla jednostek Armii Radzieckiej w Legnicy, informował Delegat Rządu RP przy Dowództwie Polskiej Grupy Wojsk Armii Radzieckiej (PGWAR). Według jego słów brak kontroli władz oświatowych „stwarza warunki nieprawidłowego lub nawet szkodliwego nauczania" ${ }^{63}$. Do szkół miało uczęszczać 140 osób. Legnica nie była zresztą jedynym przykładem takich praktyk.

W nauczaniu po niemiecku uczestniczyli także autochtoni ${ }^{64}$. O takim przypadku informowali m.in. działacze Związku Nauczycielstwa Polskiego przebywający w związkowym ośrodku w Kudowie Zdroju ${ }^{65}$. Nauczanie w języku niemieckim, a także działalność antypolską mieli prowadzić Gertruda Janitz, autochtonka, która przeszła pozytywną weryfikację (choć po sprawdzeniu sprawy przez starostwo kłodzkie okazało się, że niesłusz-

${ }^{60}$ AP Wrocław, Urząd Wojewódzki we Wrocławiu, sygn. VI/306, Pismo wojewody wrocławskiego z 15 III 1948 r., s. 17.

${ }^{61}$ Tzw. wybitni specjaliści.

${ }^{62}$ AP Wrocław PWRN KOS, sygn. XVII/92, Pismo Kuratorium Okręgu Szkolnego z 6 IV 1950 r., s. 145.

63 AAN, Ministerstwo Oświaty, sygn. 1749, Pismo z lutego 1951 roku pułk. Teodora Kusznierka Delegata Rządu RP przy Dowództwie PGWAR, s. 413.

${ }^{64}$ Ludność zamieszkująca byłe ziemie niemieckie przyłączone do Polski w 1945 r. a legitymująca się (w założeniu władz polskich) pochodzeniem polskim. Ludność ta podlegała procesowi weryfikacji, który miał potwierdzić „polska przynależnośc”, cyt. za: M. Hejger, Przeksztatcenia narodowościowe na Ziemiach Zachodnich i Pótnocnych Polski w latach 1945-1959, Słupsk 2008, s. 130.

${ }^{65}$ AAN, Ministerstwo Oświaty, sygn. 467, Pismo ZNP z 25 IX 1948 r. do Ministerstwa Oświaty, s. 115. 
nie), oraz ksiądz Oswald Tyc ${ }^{66}$. Nauczycielka, udzielając lekcji, tym samym „odciągała dzieci autochtonów od polskiej szkoły”.

Zdarzało się, że już po oficjalnym otwarciu szkół niemieckich, te „półlegalne” instytucje działały nadal, ciesząc się większym zainteresowaniem niż państwowe. Wynikało to z faktu, że Niemcy nie mieli zaufania do polskich placówek, obawiając się polonizacji ich dzieci, ponadto część rodziców uważała, że wkrótce opuszczą Polskę, więc nie ma sensu, aby dzieci rozpoczynały edukację w polskiej szkole.

Podstawą prawną do nauczania od 1950 roku było zarządzenie Ministerstwa Oświaty z dnia 26 VII 1950 roku w sprawie otwarcia przedszkoli i szkół z niemieckim językiem nauczania ${ }^{67}$. W zarządzeniu znalazł się zapis:

Dla dzieci i młodzieży narodowości niemieckiej, których prawni przedstawiciele pragną je kształcić w języku ojczystym, otwierane będą przedszkola oraz szkoły ogólnokształcące stopnia podstawowego i licealnego z niemieckim językiem nauczania. Przy zakładaniu przedszkoli i szkół $\mathrm{z}$ niemieckim językiem nauczania stosowane będą te same zasady organizacyjne i normy, jakie stosuje się przy zakładaniu analogicznego typu szkół z polskim językiem nauczania ${ }^{68}$.

Szczegółowych informacji na temat organizacji placówek dostarczała instrukcja Ministerstwa Oświaty z 3 VIII 1950 roku. Wprowadzała m.in. język polski od II klasy a od I język ojczysty mniejszości narodowej, czyli język niemiecki. Nauczenie większości przedmiotów miało odbywać się w języku narodowym (podobnie jak w szkołach żydowskich i ukraińskich), w języku polskim prowadzona była nauka o konstytucji, wychowanie fizyczne, przysposobienie wojskowe i oczywiście język polski. Podobnie jak w przypadku wyżej omówionych szkół mniejszości narodowych, również w szkołach niemieckich do nauczania miały zostać wprowadzone elemen-

${ }^{66}$ AAN, Ministerstwo Oświaty, sygn. 467, Pismo Naczelnika Departamentu Politycznego Ministerstwa Administracji Publicznej do Ministerstwa Oświaty 7 III 1949; Pismo ZNP z 25 IX 1948 r. do Ministerstwa Oświaty.

${ }_{67}$ Zarządzenie Ministerstwa Oświaty z 26 VII 1950, Dz. U. Ministerstwa Oświaty, 150, nr 14, poz. 177 .

${ }^{68} \mathrm{Za}$ J. Dudek, op. cit., s. 77. 
ty historii ojczystej, zaś w ramach lekcji śpiewu uwzględniono muzykę ojczystą.

Wydział Oświaty Prezydium Wojewódzkiej Rady Narodowej (PWRN) we Wrocławiu uruchomił w 1950 roku 28 szkół siedmioklasowych z 96 nauczycielami dla 3079 uczniów. W kolejnym roku działały 42 szkoły, w których naukę pobierało 4065 uczniów pod opieką 124 nauczycieli; w 1952 roku odnotowano 51 szkół, 4203 uczniów i 148 nauczycieli, a w 1953 roku - 54 placówki, 4299 uczących się dzieci, 151 pedagogów. Podobnie było w następnym roku. Mimo dużej liczby szkół i uczniów, nie wszystkie dzieci objęte były powszechnym nauczaniem: część Niemców nie chciała posyłać swoich potomków do polskich placówek, natomiast inni nie robili tego ze względu na zbyt dużą odległość do najbliższego punktu nauczania. Do sytuacji takich dochodziło, gdy ze względu na rozproszenie nie było możliwości zorganizowania szkół czy klas we wszystkich miejscowościach zamieszkiwanych przez Niemców. Zainteresowanie ze strony rodziców i dzieci placówkami z niemieckim językiem nauczania stopniowo jednak wzrastało. Szkoły podstawowe o takim profilu przeżywały największy rozkwit w latach 1952-1956. Po 1956 roku, w związku z wyjazdami Niemców z Polski, ich liczba zaczęła spadać. W roku szkolnym 1957/58 było ich już tylko 20 (rok wcześniej 51), w kolejnym jedynie 8, a w roku szkolnym 1962/63 funkcjonowały już tylko 2 szkoły, w których uczyło się 43 uczniów. Malejąca liczba dzieci powodowała likwidację kolejnych placówek. Niektóre działały bardzo krótko, choćby szkoła w Kunicach została zamknięta już w 1953 roku $^{69}$. W kolejnych latach zdarzało się, że nawet $\mathrm{w}$ trakcie roku szkolnego władze oświatowe dokonywały reorganizacji szkół. Ostatnie szkoły z niemieckim językiem nauczania istniały w Legnicy i we Wrocławiu. Obie zakończyły działalność w 1963 roku.

Znacznie krócej działały szkoły średnie z niemieckim językiem nauczania. W roku szkolnym 1952/53 otwarto w Świdnicy przy polskim liceum pedagogicznym równoległą klasę I z niemieckim językiem nauczania, a od 1 IX kolejnego roku zaczęło działać liceum ogólnokształcące

${ }^{69}$ Dzieci przeszły do polskiej szkoły, w której zorganizowano im komplety z języka niemieckiego. B. Ociepka, Niemcy na Dolnym Ślasku w latach 1945-1970, Wrocław 1992, s. 109. 
w Wałbrzychu. VIII klasę z niemieckim językiem nauczania uruchomiono w SP nr 1 w Wałbrzychu, łącząc szkołę średnią z dotychczasową podstawówką (ułatwiło to wyposażenie szkoły w sprzęt i pomoce naukowe). Klasę niemiecką w liceum świdnickim utworzono z myślą o przygotowaniu kadr dla tego szkolnictwa. Niestety niewielu młodych Niemców było zainteresowanych zdobywaniem kwalifikacji pedagogicznych. Szkoła (klasa „niemiecka”) działała w latach 1952-1958. Dwukrotnie odbyła się matura grupy niemieckiej: w 1956 roku 25 osób zdało tam egzamin dojrzałości zaś w 1958 roku już tylko 8 osób. W 1957 roku nie utworzono już klasy I ze względu na brak chętnych. Możliwe, że wiązało się to z powstaniem liceum ogólnokształcącego, które cieszyło się znacznie większym zainteresowaniem niż szkoła w Świdnicy. Trzeba jednak przyznać, że liceum również nie działało długo; maturę zdało tam zaledwie 20 uczniów, a w 1958 roku szkołę zamknięto ${ }^{70}$. Podobnie jak w przypadku szkół podstawowych, przyczyniła się do tego przede wszystkim emigracja Niemców.

$\mathrm{Na}$ Dolnym Śląsku funkcjonowały też dwie szkoły zawodowe, które umożliwiały zdobycie kwalifikacji przez młodzież niemiecką (Zawodowa Szkoła Górnicza w Wałbrzychu i Szkoła Przemysłowo-Górnicza w Boguszowie). Obie zostały jednak wkrótce zamknięte - w 1955 roku spotkało to szkołę boguszowską, a w 1958 roku wałbrzyską ${ }^{71}$. W Wałbrzychu krótko (i półlegalnie) działało również prywatne liceum ogólnokształcące założone przez samych zainteresowanych ${ }^{72}$.

W pierwszych latach po II wojnie światowej nie było możliwości oficjalnego nauczania języka ukraińskiego ${ }^{73}$. Uwarunkowania historyczne, a przede wszystkim akcja "Wisła”, wpłynęły na stosunki polsko-ukraiń-

${ }^{70}$ AP Wrocław, PWRN KOS, sygn. XVII/93, M. Zygmunt, „Szkolnictwo z niemieckim językiem nauczania na terenie województwa wrocławskiego w okresie powojennym" [maszynopis], s. 103.

71 B. Ociepka, op. cit., s. 113.

72 Ibidem.

73 Szkoły ukraińskie były tworzone na przełomie 1944/1945 r., ale już w 1945 r., wobec toczącej się akcji wysiedleńczej, szkolnictwo ukraińskie zostało przez władze zlikwidowane. Zob. R. Drozd, Szkolnictwo ukrainskie w Polsce w latach 1944-1989-próba periodyzacji, „Rocznik Lubuski” 2004, t. 30, cz. 1, s. 25-37. O braku możliwości nauczania także: AAN, PZPR, sygn. 237/XIV-146, s. 123. 
skie i tym samych na pozycję Ukraińców w państwie polskim. Działania władz zmierzały do pełnej polonizacji Ukraińców ${ }^{74}$, toteż podejmowanie przedsięwzięć, które mogły służyć rozwojowi kultury narodowej czy pielęgnowaniu języka ukraińskiego nie było możliwe. Jednak na początku lat pięćdziesiątych XX wieku pojawiły się pewne symptomy zmian. Na posiedzeniach Sekretariatu KC PZPR w 1951 roku podejmowano problematykę ukraińską. Możliwe, że nastąpiło to $\mathrm{w}$ tym momencie $\mathrm{z}$ powodu nasilających się tendencji powrotów tej ludności na rodzime ziemie i nadużyć administracyjnych przy powtórnym przesiedlaniu. Rozważano możliwość zmiany stosunku do Ukraińców, choćby poprzez umożliwienie im swobodnego posługiwania się językiem ojczystym i wprowadzenie jako dodatkowego przedmiotu języka ukraińskiego w szkołach z przewagą dzieci ukraińskich ${ }^{75}$. Modyfikacja polityki wobec Ukraińców w dużej mierze wynikała więc z chęci „ustabilizowania” tej ludności na Ziemiach Zachodnich i Północnych. Władze uznały, że łatwiej będzie doprowadzić do adaptacji, kiedy nastąpi przyzwolenie ze strony samych zainteresowanych, dlatego zezwoliły na ograniczony (a zarazem kontrolowany przez państwo) rozwój działalności kulturalnej i oświatowej ${ }^{76}$.

W pierwszych latach po wprowadzeniu nauczania języka ukraińskiego jedyną zorganizowaną formą edukacji wspomnianego języka były punkty nauczania. W 1956 roku nastąpiły zmiany. Na terenie Jaroszówki powstała ukraińska szkoła podstawowa, a w Złotoryi, a następnie w Legnicy szkoła średnia. Nauka języka ukraińskiego opierała się o rozporządzenie Ministerstwa Oświaty z 20 VIII 1952 roku regulujące formy i zakres nauczania dzieci „niepolskich” w ojczystym języku ${ }^{77}$. Dodatkowo, powiatowe

${ }^{74}$ AP Wrocław, Urząd Wojewódzki Wrocławski, sygn.VI/743, k. 140.

75 AAN, Archiwum Bolesława Bieruta, sygn. 254/IV-22, Notatka dotycząca ludności ukraińskiej w Polsce, k. 170-176.

76 Warto zauważyć, że przedstawiciele władzy lokalnej nie zawsze widzieli potrzebę zmiany polityki wobec Ukraińców, toteż zdarzały się sytuacje, że utrudniano zorganizowanie kompletów z języka ukraińskiego. Więcej na temat polityki zob. L. Olejnik, op. cit., s. 316.

77 Obowiązywało do 4 XII 1956 r. Modyfikacja nastąpiła w 1959 r. i w takim kształcie funkcjonowało do 1992 r. J. Syrnyk, Ludność ukraińska na Dolnym Ślasku (1945-1989), Wrocław 2007, s. 192. 
Wydziały Oświaty otrzymały „Wytyczne w sprawie pracy na odcinku grup narodowościowych" (1 VII 1953), które precyzowały kwestie organizacyj$n \mathrm{e}^{78}$. Nauczanie języka ukraińskiego miało być wprowadzane na „wyraźne życzenie rodziców" od II klasy szkoły podstawowej lub na kompletach dla co najmniej dziesięciorga uczniów, przez 3 godziny tygodniowo ${ }^{79}$. Dodatkowe lekcje z języka ukraińskiego miały być wprowadzane wtedy, gdy stwierdzono wyraźną potrzebę ich zorganizowania ${ }^{80}$. Rok 1956 przyniósł kolejne regulacje prawne dotyczące nauczania języka ukraińskiego ${ }^{81}$. Zgodnie z nimi nauczanie wprowadzano do szkoły, w której co najmniej 7 uczniów w klasach od II do VII zostało przez rodziców zapisanych na naukę tego przedmiotu. W uzasadnionych przypadkach (kiedy istniała bliska realna perspektywa wzrostu liczby uczniów lub konieczność zapewnienia ciaggłości nauczania) można było edukować mniejszą liczbę dzieci. Uwzględniano także możliwość tworzenia kompletów obejmujących uczniów z różnych poziomów klas. Zachowano liczbę 3 godzin zajęć w tygodniu, jednoznacznie określono także, że język ukraiński ma być wpisywany na świadectwie po wychowaniu fizycznym. Przypominano również, że rozkłady materiału i tematy w dziennikach mają być wpisywane po ukraińsku, natomiast pozostała dokumentacja prowadzona $\mathrm{w}$ języku polskim ${ }^{82}$. Jeżeli nauka odbywa się w komplecie złożonym z uczniów różnych klas, rozkłady materiału, tematykę lekcji i hospitacje wpisywano w jednym z dzienników lekcyjnych, a stopnie i frekwencję w tych dziennikach lekcyjnych, w których zapisani byli poszczególni uczniowie. W efekcie zaistniałych zmian na terenie

${ }^{78} \mathrm{O}$ zmianach sytuacji politycznej umożliwiającej kształtowanie się szkolnictwa ukraińskiego także: M. Iwanicki, Ukraincy, Biatorusini, Litwini i Niemcy w Polsce w latach 1918-1990, Siedlce 1990, s. 77.

79 J. Dudek, op. cit., s. 88.

80 AP Wrocław, PWRN KOS, sygn. XVII/89, k. 49.

${ }^{81}$ Okólnik Ministerstwa Oświaty Nr 30 z 4 XII 1956 r., nr SO 5-645/56, Dz. U. Ministerstwa Oświaty nr 15, poz. 148 oraz pismo okólnik Ministerstwa Oświaty z 12 XII 1959 r. nr SO 4 - 4816/59), AP Legnica, PPRN w Lubinie, sygn. 665. b. p. Nieznacznie modyfikowały nauczanie języka ukraińskiego okólniki Ministerstwa Oświaty z 27 XII 1960 r. i 23 IX 1981 r. oraz Rozporządzenie Ministra Oświaty i Wychowania nr 67 z 21 X 1987.

${ }^{82}$ Pismo Ministerstwa Oświaty z 27 XII 1959 r., AP Legnica, PPRN w Lubinie, sygn. 664 , b. p. 
całego kraju powstawały punkty nauczania języka ukraińskiego. Niektóre punkty (jak w Jakuszowie) działały bardzo krótko, inne - jak w Kawicach czy Legnickim Polu - przez lata mogły stanowić zaplecze rekrutacyjne dla legnickiego liceum. Najwięcej punktów nauczania funkcjonowało na terenie Dolnego Śląska pod koniec lat pięćdziesiątych. Szczyt działalności tych punktów przypadł na rok szkolny 1958/1959, kiedy było ich 23. W sumie w różnych okresach zajęcia prowadzono w 41 miejscowościach (m.in.: Bukówna, Chomiąża, Gawrony, Gniewomierz, Gromadka, Jakubów, Kębłów, Kostomłoty, Kościelec, Konary, Lubiąż, Kawice, Lasowice, Legnica, Legnickie Pole, Lubin, Lubniów, Michałów, Mikołajowice, Mierzowice, Modła, Mójęcice, Moskorzyn, Niemstów, Orsk, Orzeszków, Połczyn, Pomocne, Prochowice, Piechowice, Piersno, Radoszyce, Rosochata, Rudna, Siedlce, Słup, Szczepanów, Udanin, Wądroże Wielkie, Wołów, Wrocław) ${ }^{83}$. Faktycznie liczba punktów rokrocznie podlegała zmianom. Nie zawsze też nauka języka ukraińskiego była uruchamiana tam, gdzie została zgłoszona lub monitoring władz oświatowych wskazywał potrzebę. PWRN przesłało do Ministerstwa Oświaty (wcześniej zebrane od powiatowych władz) informacje o liczbie dzieci z rodzin ukraińskich uczęszczających do polskich szkół. W roku szkolnym 1952/53 było ich 610. Okazało się jednak, że wolę nauczania wyrazili rodzice tylko 286 spośród nich, czyli niespełna $47 \%{ }^{84}$. Ponadto w niektórych planowanych punktach nie rozpoczęto zajęć ze względu na brak nauczycieli lub zbyt małą liczbę uczniów (niewystarczającą do uruchomienia kursu zgodnie z założeniami ustawy).

Jedyne dwie szkoły ukraińskie działały na Dolnym Śląsku - podstawowa w Jaroszówce, a średnia w Legnicy. Placówka w Jaroszówce została uruchomiona w roku szkolnym 1956/7, ale faktycznie zajęcia rozpoczęły się 15 I 1957 roku; szkoła funkcjonowała do 1975 roku.

„Legnicki” okres liceum rozpoczął się 1 IX 1960 roku, choć faktycznie placówka ukraińska zainicjowała swoją działalność już 3 lata wcześniej, ale wówczas 22 uczniów rozpoczęło edukację w Złotoryi, ponieważ w Legnicy

${ }^{83} \mathrm{O}$ rozmieszczeniu szkół i punktów nauki języka ukraińskiego m.in. AP Wrocław, PWRN KOS, XVII/92, k. 318, 349, XVII/90, k. 93, 138-140, 203.

${ }^{84}$ AAN, Ministerstwo Oświaty, sygn. 1752, Zestawienie uczniów pragnących uczyć się języka ukraińskiego, k. 229-231. 
brakowało pomieszczeń do prowadzenia nauki ${ }^{85}$. Szkoła, przechodząc reorganizacje związane z reformami, działa do dzisiaj.

\section{Problemy szkolnictua „mniejszościouego”}

Bardzo często w początkach swojej działalności szkoły dla mniejszości narodowych miały poważne problemy lokalowe. Zwykle w pierwszych miesiącach lub nawet latach dzieliły przestrzeń ze szkołami polskimi. Dla przykładu w Wałbrzychu niemiecka szkoła podstawowa korzystała z kilku sal lekcyjnych szkoły stopnia podstawowego i licealnego Towarzystwa Przyjaciół Dzieci ${ }^{86}$. Nawet jeśli placówki te posiadały własne budynki to zwykle były one w złym stanie i wymagały remontów, na które brakowało funduszy. Ani miejskie rady narodowe, ani powiatowe czy wojewódzkie nie spieszyły się z przyznawaniem jakichkolwiek dotacji, które mogłyby poprawić stan budynków szkolnych ${ }^{87}$. Zwykle pieniądze starczały na podstawowe naprawy albo $\mathrm{z}$ powodu braku funduszy planowane remonty przeciagały się, utrudniając nauczanie. W opisach szkół często podkreślano panujące w nich trudne warunki:

Budynek szkolny jest rozległy, brudny, dach przecieka [...]. W całym budynku nie ma ani jednej szafy, biurka, krzeseł, książki leżą na podłodze, znikoma ilość ławek szkolnych, brak zupełnie pomocy naukowych. Szkoła do której uczęszcza 280 dzieci (z powiatu ma przybyć jeszcze 100 dzieci) ma tylko jedną ubikację w parterowym korytarzu w formie szafy. Dwie ubikacje na podwórzu są zdewastowane. W przybudówce

85 O problemach ze znalezieniem i przyznaniem lokalu na szkołę ukraińską znajdujemy informację w pismach Prezydium Miejskiej Rady Narodowej i Wojewódzkiej Rady Narodowej, AP Legnica, PMRN w Legnicy, sygn. 475, s. 93-96.

${ }^{86}$ AAN, Ministerstwo Oświaty, sygn. 1749; Sprawozdanie Dyrekcji z 28 IX 1951, s. 194.

87 „Wydział Oświaty nie interesuje się szkołą, na remont pieniędzy odmówił, kwoty przeznaczone na remont szkoły wydał na inne cele. Nie pomógł w załatwieniu transportu przydzielonych mebli”. Ibidem, s. 329. Taką informację znajdujemy odnośnie szkoły dla dzieci niemieckich w Legnicy. 
mieści się duża sala gimnastyczna. W dużych oknach wszystkie szyby wybite, boazerie drewniane wewnątrz sali wykradzione, ściany brudne ${ }^{88}$.

Opis stanu szkoły funkcjonującej w POW dla dzieci greckich i macedońskich też budził zastrzeżenia: „Pomieszczenie to w zupełności nie nadaje się na szkołę, a to z tego powodu, że sale szkolne nie mają dość światła. Korytarze stosunkowo za wąskie, żeby pomieścić taką ilość dzieci jaka przebywa w szkole" ${ }^{\nexists 2}$. I jeszcze przykład szkoły żydowskiej:

Budynek szkoły nr $6 \mathrm{w}$ Bielawie nie nadaje się na szkołę. Może on pomieścić maksimum 80 osób a będzie się uczyło 182. Położony jest między kanałem ściekowym a ruchliwą ulicą. Brak boiska szkolnego, działki szkolnej. Sprzęt stary, zniszczony, poniemiecki, wymaga wymiany. Brak częściowo pomocy naukowych do fizyki a zupełnie do biologii ${ }^{90}$.

Prawie we wszystkich sprawozdaniach dotyczących żydowskich szkół odnajdujemy informację o koniecznych remontach (Wałbrzych, Wrocław, Legnica, Dzierżoniów) ${ }^{91}$, a tylko nieliczne wskazują na to, że budynki się tych remontów doczekały. Obok opłakanego stanu budynków podkreślano także brak pomocy naukowych „w skutek czego w nauczaniu fizyki, chemii biologii i geografii kwitnie werbalizm"92.

Nie mniej istotny od trudności lokalowych był brak wykwalifikowanej kadry, który nękał szkolnictwo wszystkich grup mniejszościowych. Chcąc doraźnie rozwiązać ten problem, na wniosek ministerstwa, Wydziały Oświaty Rad Narodowych organizowały krótkie kursy przygotowawcze, kursy wakacyjne lub powoływały Komisje Rejonowe. W przypadku szkolnictwa niemieckiego nauczycieli rekrutowano spośród „postępowych ro-

88 Wyciąg ze sprawozdania dot. szkolnictwa niemieckiego z terenu m. Legnicy wysłany przez Biuro Społeczno-Administracyjne Urzędu Rady Miejskiej do Ministerstwa Oświaty Wydziału Szkół z Niepolskim Językiem Nauczania 3 X 1953. Ibidem, s. 329.

89 Sprawozdanie ze stanu Szkoły Podstawowej POW za okres trzeci roku szkolnego 1950/51, Macedońscy uchodźcy..., t. 2, s. 264.

90 AP Wrocław, PWRN KOS, sygn. XVII/90 s. 123-125.

${ }^{91}$ Ibidem.

92 AAN, Ministerstwo Oświaty, sygn.1764, Informacja o szkołach utrzymywanych przez CKŻP, s. 42. 
botników” i innych pracowników narodowości niemieckiej władających językiem polskim ${ }^{93}$. W proces rekrutacji bardzo aktywnie włączały się komitety powiatowe PZPR, a zwłaszcza Związek Zawodowy Górników ${ }^{94}$. Nauczycielami w szkołach niemieckich na terenach wiejskich byli często pracownicy PGR ${ }^{95}$, co miało pewne uzasadnienie „ideologiczne”. Władze uznały, że najlepiej z zadań nauczania i wychowania dzieci niemieckich w duchu "patriotyzmu proletariackiego i internacjonalizmu” wywiążą się przodownicy pracy w kopalniach i innych dolnośląskich zakładach. Obawiano się nauczycieli przedwojennych, wychodząc z założenia, że zostali „skażeni faszyzmem” i, jako byli członkowie NSDAP, nie będą potrafili wyzwolić się z modelu wychowawczego proponowanego przez narodowy socjalizm. Kursy, na których przyszli nauczyciele zdobywali kwalifikacje, były organizowane zwykle w czasie wakacji i ferii zimowych. Przeważnie prowadzili je polscy pedagodzy znający język niemiecki, wśród wykładowców byli także wizytatorzy szkół z niepolskim językiem nauczania. Na początku 1952 roku zorganizowano także Komisję Rejonową Kształcenia Nauczycieli szkół z niemieckim językiem nauczania, która pozwalała na zdobycie wykształcenia i nabycie kwalifikacji eksternistycznie. Dzielono kandydatów na trzy grupy, w zależności od wykształcenia, różnicując czas zdobywania kwalifikacji (od roku dla tych, którzy mieli świadectwo licealne, trzy lata dla tych, którzy ukończyli gimnazja i pięć dla kończących szkoły niższe ${ }^{96}$. Także w przypadku pozostałych mniejszości narodowych właśnie kursy wakacyjne stawały się najczęściej wykorzystywaną formą zdobywania kwalifikacji. Wydział Oświaty Wojewódzkiego Komitetu Żydowskiego już w 1947 roku organizował kursy dla nauczycieli we Wrocławiu, z których przede wszystkim korzystali dolnośląscy pedagodzy (na 48 uczestników 35 pochodziło z Dolnego Śląska). Także na Ogólnopolskiej Konferencji

93 J. Dudek, op. cit., s. 76.

${ }^{94}$ AP Wrocław, PWRN KOS XVII/93, M. Zygmunt, Szkolnictwo z niemieckim językiem nauczani na terenie województwa wrocławskiego w okresie powojennym [maszynopis], s. 41.

${ }_{95}$ Przy okazji nierzadko informatorzy Urzędu Bezpieczeństwa Publicznego. M. Hejger, op. cit., s. 117.

96 A. Smołalski, Szkolnictwo podstawowe na Dolnym Ślasku w latach 1945-1965, Wroctaw 1970, s. 138-139. 
Nauczycieli Żydowskich w listopadzie 1946 roku było ponad 70 nauczycieli z Dolnego Śląska ${ }^{97}$.

Z kolei pierwszymi nauczycielkami dzieci greckich i macedońskich były 18-20 letnie dziewczęta, które przybyły z nimi z Grecji i same miały ukończone 5-7 klass ${ }^{98}$. Ponieważ wyraźnie brakowało im umiejętności (przerabiały ten sam materiał po kilka razy w ten sam sposób...), zorganizowano dla nich pierwszy kurs doszkalający w marcu 1949 roku w Solicach Zdroju, w którym wzięło udział 50 osób ${ }^{99}$. Metoda wyszukiwania wychowawców i nauczycieli spośród najstarszej grupy emigrantów stanowiła $\mathrm{w}$ początkach organizowania szkolnictwa greckiego i macedońskiego regu$\mathrm{łę}^{100}$. Niemniej w sprawozdaniach z działalności ośrodka w Lądku pojawia się informacja o tym, że lepiej opierać się na nauczycielach polskich, którzy są lepszym „narybkiem” pedagogicznym, szybko też opanowują język macedoński czy grecki i lepiej radzą sobie z nauczaniem. Najprawdopodobniej chodziło również o zniwelowanie innego problemu, który w tym konkretnym szkolnictwie się pojawiał, a opierał się o antagonizm narodowościowy grecko-macedoński. Jak zauważali sami Macedończycy, w Polsce otrzymali szansę nauki we własnym języku, której nie mieli w Grecji, gdzie byli traktowani jak „obywatele gorszej kategorii”. To równouprawnienie wzbudzało niechęć części Greków, przez co polscy wychowawcy zwracali uwagę, że często zdarzały się przypadki dyskryminacji dzieci macedońskich przez greckich nauczycieli i wychowawców ${ }^{101}$. To nie był jedyny powód niechęci polskich wychowawców do greckich. Polacy nie akceptowali ich metod wychowawczych, które opierały się o żelazną, prawie wojskową dyscyplinę i stosowali surowe metody wychowawcze i kary ${ }^{102}$, organizowali też nocne

${ }^{77}$ B. Szaynok, Ludność żydowska na Dolnym Śląsku 1945-1950, Wrocław 2000, s. 123.

98 Sprawozdanie $\mathrm{z}$ pobytu dzieci greckich i macedońskich w Lądku Zdroju, Macedońscy uchodźcy..., t. 2, s. 106.

${ }^{9}$ M. Wojecki, op. cit., s. 10.

100 Wspomina o tym: A. Kurpiel, Cztery nazwiska i dwa imiona. Macedońscy uchodźcy wojenni na Dolnym Ślasku, Poznań 2015.

${ }^{101}$ Oświadczenie w sprawie złego stosunku personelu greckiego do dzieci macedońskich, Macedońscy uchodźcy..., t. 2, s. 204-206.

102 A. Kurpiel, Cztery nazwiska i dwa imiona..., s. 101-104. 
zbiórki, apele. Prawdopodobnie miało to utrzymać, zwłaszcza starszych wychowanków, w „gotowości bojowej” i przygotować ich do ewentualnej walki (wychować na „przyszłych partyzantów”). Greccy nauczyciele zniechęcali też młodych emigrantów do nauki zwłaszcza języka polskiego, uznając to za bezcelowe, ponieważ liczyli na rychłe opuszczenie Polski ${ }^{103}$.

Także Ministerstwo Oświaty wysuwało liczne sugestie zaradzenia problemowi braku wykwalifikowanej kadry w szkołach mniejszościowych. Zalecało lokalnym kuratoriom, aby kierowały do szkół z niepolskim językiem nauczania nauczycieli rekrutujących się ze środowisk mniejszościowych, a nie proponowali im polskich placówek oświatowych. Podkreślano także, że w dziedzinie pozyskiwania kadr Ministerstwo Oświaty musi współpracować z Towarzystwami Narodowościowymi, które mają na pewno rozeznanie w „zasobach kadrowych” ${ }^{104}$, jak też z Ministerstwem Szkolnictwa Wyższego w celu opracowania planu i monitorowania kierunków kształcenia kadry dla szkół niepolskich. W Wojewódzkich Ośrodkach Doskonalenia Kadr Oświatowych powinny być powołane sekcje języków obcych kształcące instruktorów organizujących pracę zespołów metodycznych i przygotowujących kursy (zwłaszcza j. ukraińskiego) ${ }^{105}$. Potrzebę tę podkreślano, ponieważ mimo zapewnień władz oświatowych ${ }^{106}$ o odpowiednim przygotowaniu pedagogów do nauczania języka ukraińskiego, wielu uczących języka ukraińskiego tak naprawdę nie tylko nie miało wykształcenia kierunkowego, ale również miało spore braki w znajomości tego języka. KOS Wrocławskiego skłonne było na początku lat sześćdziesiątych zatrudniać w punktach osoby niebędące nauczycielami, ale znające

${ }^{103}$ Mówiono wręcz o „niewłaściwym oddziaływaniu towarzyszy greckich na dzieci”, „Sprawozdanie Dyrektora Naczelnego POW za I kwartał roku 1951”, [w:] Macedońscy uchodźcy..., s. 234.

${ }^{104}$ AP Wrocław PWRN KOS, sygn. XVII/92, Protokół z posiedzenia międzywydziałowego, s. 136-137. Poszczególne towarzystwa mniejszościowe włączały i optowały u władz oświatowych, aby te zorganizowały kierunki studiów lub klasy w liceach pedagogicznych, które pozwoliłyby wykształcić kadry dla szkolnictwa.

105 AAN, Ministerstwo Oświaty, sygn. 1795, Wnioski Komisji KCPZPR ds. Narodowościowych dotyczące dalszego rozwoju szkolnictwa dla mniejszości narodowych, 28 VIII 1957, s. 4.

106 O tym przekonywali urzędnicy Wydziały Oświaty WRN we Wrocławiu. Zob. AAN, Ministerstwo Oświaty, sygn. 1752, s. 228. 
język ukraiński ${ }^{107}$. Nie bez znaczenia było też to, że mający kwalifikacje do nauczania nie zawsze chcieli je prowadzić108. W pismach ministerialnych, jak również w opiniach wizytatorów wojewódzkich podkreślano, że szkolnictwo mniejszościowe potrzebuje właściwego nadzoru do prawidłowego funkcjonowania, stąd konieczność tworzenia dodatkowych etatów dla wizytatorów szkół narodowościowych i podinspektorów szkół narodowościowych ze znajomością języka mniejszości. W pierwszych latach powstawania placówek dla ludności niepolskiej ministerstwo monitorowało ten problem, wysyłając do PWRN prośby o przekazywanie zestawień dotyczących wykształcenia nauczycieli, m.in. w celu ustalenia potrzeb w zakresie przygotowania kursów kwalifikacyjnych ${ }^{109}$.

Kiedy przybywało szkół dla kolejnych mniejszości narodowych, Departament Kadr i Narodowościowy Ministerstwa Oświaty starał się pozyskiwać pedagogów wśród polskich nauczycieli, którzy biegle posługiwali się językami, w jakich nauczano we wspomnianych placówkach. Poszukiwania pedagogów chętnych do pracy w szkołach z niepolskim językiem nauczania prowadzono też w ramach realizacji „zobowiązania pierwszomajowego" ${ }^{110}$. Ministerstwo dostrzegało zalety zatrudniania nauczycieli Polaków w szkołach dla mniejszości. Miało to „wzmocnić to szkolnictwo i zespolić je ściślej niż dotychczas ze szkolnictwem polskim"111.

Ważnym elementem szkół mniejszościowych (podobnie jak polskich) była właściwa postawa nauczycieli. W przypadku szkolnictwa z niepolskim językiem nauczania obok „wyrobienia ideologicznego" zwracano uwagę na to, czy pedagodzy nie wychowują w duchu "nacjonalizmu” (ukraińskiego, syjonizmu czy „faszyzmu”). Pedagodzy podlegali inwigilacji służb bezpie-

107 AP Legnica, PPRN w Lubinie, 663, Pismo Kuratorium Okręgu Szkolnego we Wrocławiu do Inspektoratu Oświaty PPRN w Lubinie z 14 I 1960, k. 8.

${ }^{108}$ Ministerstwo Oświaty miało dysponować listą, na której było ponad 2 tys. osób, które mogły nauczać języka ukraińskiego, natomiast do pracy zgłaszały się pojedyncze osoby. Może czynnikiem zniechęcającym był brak perspektyw. Często zdarzało się też, że punkty nauczania działały bardzo krótko. J. Syrnyk, Ludność ukraińska..., s. 195.

109 AAN, Ministerstwo Oświaty, sygn. 1749, s. 143-144.

110 AAN, Ministerstwo Oświaty, sygn. 1749, Notatka dla Obywatela Ministra z 8 V 1952 roku, s. 226.

111 Ibidem, s. 228. 
czeństwa ${ }^{112}$. Także w dokumentach wydziałów rad narodowych odnajdujemy informacje przekazywane przez wizytatorów czy „donosicieli” piętnujące niewłaściwe zachowania nauczycieli. $\mathrm{Na}$ przykład w legnickiej szkole uczyły osoby, co do których poglądów i „reputacji” były wyraźne zastrzeżenia. Byli wśród nich: nauczyciel „Hiller, były członek Hitlerjugend, przedmioty polityczne wykłada spacerując po pulpitach, albo siedząc na piecu i piejąc jak kogut. Opowiada dzieciom, że armia brunatna wnet wkroczy do Polski, że wstydem jest, że żydzi służą w polskiej armii” oraz dawny Oberstleutnant lotnictwa, „który jest negatywnie nastawiony do naszej rzeczywistości" ${ }^{113}$. Właśnie za niewłaściwy stosunek do PRL zwolnieni zostali w roku szkolnym 1951/52 nauczyciele z niemieckiej szkoły w Legnicy. Jak tłumaczyły władze:

Opowiedzenie się po czyjej stronie stoi nauczyciel przesądza pracę szkoły. Czyż nauczyciel, który widzi zbawienie narodu niemieckiego w Niemczech Zachodnich mógtby wychowywać młodzież według zasad pedagogiki socjalistycznej? Tu nie ma wyboru. Nauczyciel musi zając wyraźne stanowisko zwłaszcza w obecnej sytuacji, kiedy rząd Adenauera wszedł na drogę zbrojeń, przygotowania armii napastniczej pod rozkazami USA ${ }^{114}$.

Celem nauczania szkół niemieckich (oraz placówek innych narodowości) miało być „wychowanie młodzieży w duchu internacjonalizmu na

112 M.in. takiej inwigilacji podlegał dyrektor szkoły żydowskiej w Legnicy (pełniący zresztą też funkcję dyrektora szkoły ukraińskiej) Mendel Tanencapf, Archiwum Instytutu Pamięci Narodowej oddział we Wrocławiu (dalej: IPN Wrocław), sygn. 022/216, t. 2, s. 4; Służba Bezpieczeństwa w Legnicy rozpracowywała w ramach sprawy o kryptonimie „Żurawie” Jana Śpiwaka, Jana Olejnika, Michała Bzdela (IPN Wrocław, sygn. 0148/756), Bogdana Hnatiuka (IPN Wrocław, sygn. 022/355). Dyrektor Irena Snihur była objęta działaniami w ramach sprawy o kryptonimie „Oksana” (a później kolejnej „Modliszka”; IPN Wrocław, sygn. 022/1214). Więcej o sprawach: J. Syrnyk, Ludność ukrainska..., s. 133-138, 213.

113 AAN, Ministerstwo Oświaty, sygn.1749, Notatka dla Obywatela Ministra z 8 V 1952 roku, s. 331.

114 AP Wrocław PWRN KOS, sygn. XVII/89, Wprowadzenie do dyskusji na konferencji dyrektorów i kierowników szkół z niepolskim językiem nauczania, 18 IV 1953. 
czynnych i świadomych budowniczych PRL"115. Władze uważały, że uczeń w szkole ma nabyć taką postawę, aby oddziaływał w domu na rodziców.

Brak wykwalifikowanej kadry był też jednym z powodów, dla których narzekano na niski poziom szkół mniejszościowych. Jan Dudek, wizytator okręgowy, podkreślał, że do tych placówek uczęszczają dzieci, które nie dostałyby się do polskich szkół i podkreślał „ich słabe przygotowanie” 116 . Z tą opinią polemizowali i polemizują badacze problemów mniejszościowych, dostrzegając złożoność problemu ${ }^{117}$ i zwracając uwagę, że jednym z głównych problemów był brak właściwej opieki nadzoru pedagogicznego, ponieważ nie wszyscy wizytatorzy znali język narodowy i specyfikę kształcenia tych placówek.

Najlepiej wykształceni byli pedagodzy w szkołach żydowskich. Niestety dużym problemem tych placówek była fluktuacja kadry nauczycielskiej i brak nauczycieli znających język żydowski, hebrajski czy chcących uczyć historii Żydów. Ciągłe zmiany grona nauczycielskiego wynikały z „płynności” środowiska żydowskiego. Ta „atmosfera dworca kolejowego"118, która występowała z rozmaitym natężeniem w różnych okresach, powodowała częste zmiany i mogła mieć wpływ na obniżanie poziomu szkół czy chwilowe braki kadrowe. Nieznajomość przedmiotów żydowskich powodowała, że w placówkach żydowskich miejsce jidysz (jako języka wykładowego) zajmował język polski, często też zmniejszano liczbę lekcji języka żydowskiego poniżej przewidywanego wymiaru. Ponadto często nie znali go uczniowie, a ponieważ płynność środowiska uczniowskiego była jeszcze większa niż nauczycielskiego, nie mieli możliwości nauczenia się go. Zwłaszcza w pierwszych latach po II wojnie część uczniów posługiwała się tylko językiem polskim, a po falach repatriacji przybyli z ZSRR znali tylko rosyjski. Toteż starano się, ,aby istniejące szkoły stopniowo przechodziły na język wykładowy żydowski, z obowiązkiem nauczania hebrajskiego"119, ale w wielu placówkach stanowiło to niemałą trudność. W kolejnych la-

115 Wspominane wcześniej Zarządzenie Ministerstwa Oświaty z 20 VII 1950 r.

116 J. Dudek, op. cit., s. 92.

117 Choćby w przypadku szkolnictwa ukraińskiego kilkakrotnie wspominany Jarosław Syrnyk.

118 AP Wrocław, PWRN KOS, sygn. XVII/91, s. 31.

119 AŻIH, Prezydium CKŻP, sygn. 303/2, s. 124. 
tach znajomość języka narodowego zanikała ${ }^{120}$ przede wszystkim u tych, którzy dłużej mieszkali w Polsce. Tłumaczono to brakiem podręczników, nauczycieli (nie tylko z powodu wyjazdów, ale też zmian składu grona nauczycielskiego - w szkołach żydowskich pojawiało się coraz więcej Polaków wśród pedagogów), ale też faktem, że młodzież na co dzień posługuje się językiem polskim. W efekcie nawet sami rodzice dzieci ze szkół żydowskich proponowali odejście od nauczania jidysz ${ }^{121}$.

Jeszcze bardziej niż fluktuacja kadry dezorganizowały pracę szkoły wyjazdy uczniów. Dla przykładu: w ciągu roku szkolnego 1956/7 ze szkoły w Bielawie wyjechało 77 z 180 uczniów, w Wałbrzychu 62 ze $164^{122}$. Uczniowie nie chodzili czasami na zajęcia już kilka tygodni przed wyjazdem, a jeśli nawet uczestniczyli w zajęciach, nie przykładali się do nich. Wizytatorzy szkół niemieckich podkreślali ten sam problem ${ }^{123}$. W przypadku szkół żydowskich pod koniec lat pięćdziesiątych nastąpił krótkotrwały ${ }^{124}$ przyrost liczby uczniów w związku z repatriacjami z ZSRR, w ramach których przybyła duża grupa ludności żydowskiej. Przesiedleńców rozmieszczano przede wszystkim na terenach, na których wcześniej mieszkali Żydzi, dlatego dzieci dołączały do istniejących już szkó ${ }^{125}$. Repatriacje nie pozostały bez wpływu na możliwości realizacji programu szkolnego, co zmuszało Ministerstwo Oświaty do wprowadzenia zmian programowych, które ułatwiłyby funkcjonowanie placówek. Słaba znajomość języka polskiego i żydowskiego wśród repatriantów spowodowała, że centralna władza oświatowa wydała dyrektywę, która pozwalała na „niestosowanie się do

${ }^{120}$ AP Wrocław, PWRN KOS, sygn. XVII/88, Konferencja kierowników i dyrektorów szkół z żydowskim językiem nauczania Wrocław 4 VI 1953, s. 83.

${ }^{121}$ AP Wrocław, PWRN, KOS, sygn. XVII/88, Sprawozdanie z wizytacji szkół z żydowskim językiem nauczania w Wałbrzychu, Dzierżoniowie i Legnicy, s. 65-68.

${ }^{122}$ Na podstawie AP Wrocław, PWRN KOS, sygn. XVII/91, s. 102.

123 Por. AP Wrocław, PWRN KOS, sygn. XVII/91, s. 74; AAN, Ministerstwo Oświaty, sygn. 1753, s. 121.

${ }^{124}$ Krótkotrwały, ponieważ wielu z nich było w Polsce „tylko tranzytem”. Zresztą dlatego właśnie na temat tego okresu mówiono, że odpowiadał atmosferze „dworca kolejowego".

125 Dobrym przykładem jest szkoła w Legnicy, gdzie założenia były takie, że rok szkolny 1957/58 rozpocznie 80 uczniów, a było ich 400, natomiast w kolejnym - blisko 600. 
programu" nauczania tych dwóch przedmiotów, stosowanie ocen indywidualnych tylko w nauczaniu języka żydowskiego, natomiast jeśli chodziło o język polski, można było ucznia promować do następnej klasy nawet, gdy otrzymał ocenę niedostateczną (pod warunkiem jednak, że była to jedyna ocena niedostateczna) ${ }^{126}$.

Uczniowie szkół żydowskich nie znali jidysz, zaś nauczanie w placówkach greckich i macedońskich owocowało „zapominaniem języka rodzimego" ${ }^{\text {127. }}$. Rodzice młodych Greków i Macedończyków, jak też nauczyciele czy działacze stowarzyszeń społeczno-kulturalnych mówili o szybko postępującej polonizacji i asymilacji. Młodzi emigranci, w odróżnieniu od starszych, szybko i chętnie wrastali w polskie środowisko, przez co zajęcia w języku greckim powoli zanikały, zmniejszała się też frekwencja na tych lekcjach. Dodatkowo brak właściwego nadzoru, podręczników i słabe przygotowanie nauczycieli, którzy „na lekcji opowiadają bajki i czytają gazety” także pozostawiał wiele do życzenia ${ }^{128}$ i na pewno nie sprzyjał chęciom poznawania języka ojczystego.

Jednym z celów szkolnictwa mniejszościowego było przekazywanie informacji o „dziejach ojczystych”. Z różnych powodów, czasami związanych z sytuacją międzynarodową ${ }^{129}$, centralne władze oświatowe i partyjne miały wątpliwości, czy istnieje potrzeba funkcjonowania poszczególnych „historii narodowych” jako odrębnego przedmiotu. Po upublicznieniu szkół żydowskich państwo ograniczało także możliwość nauczania historii Żydów, wychodząc z założenia, że „nauka historii ojczystej powinna stano-

${ }^{126}$ Zalecenia obowiązywały tylko repatriantów, AP Wrocław, PWRN, KOS, sygn. XVII/91, s. 105.

127 Wytyczne do organizacji nauczania w języku greckim i macedońskim dla dzieci emigrantów greckich w roku szkolnym 1956/57, Macedońscy uchodźcy..., t. 2, s. 146-153.

128 Sprawozdanie Kole Simiczijewa z wizytacji w szkole macedońskiej w Legnicy (12 III 1958) i szkole w Zgorzelcu i Legnicy (26 IV 1960), Macedońscy uchodźcy..., t. 2, s. 252 i 308.

129 Powstanie państwa Izrael wspieranego przez Zachód, problem podzielonych Niemiec itp. 
wić integralną część historii powszechnej...”. Sugerowano jedynie uzupełnienie zajęć z historii o kilka tematów historii narodu żydowskiego ${ }^{130}$.

Kolejna rzecz (sygnalizowana wcześniej) to brak podręczników, który bardzo utrudniał proces nauczania. Nawet jeśli nauczyciel był niewykwalifikowany, a posługiwał się dobrym podręcznikiem, istniała możliwość przeprowadzenia lekcji. Pozbawiony tej pomocy dydaktycznej miał problem podwójny: brak wiedzy i brak możliwości jej uzupełnienia. W tym samym czasie uczniowie nie mieli możliwości efektywnego uczenia się ani uzupełniania zaległości. Ministerstwo Oświaty przewidywało, że odpowiedzialne za wprowadzanie na rynek podręczników Państwowe Zakłady Wydawnictw Szkolnych zaspokoją także potrzeby placówek dla mniejszości $^{131}$. Każdego roku miały powstawać plany wydawnicze uwzględniające zapotrzebowanie szkół. Niestety druk, a zwłaszcza wcześniej przygotowanie nowych książek i ich recenzowanie, trwało długo. W obliczu braku rodzimych publikacji, korzystano z pomocy sąsiedzkiej. Po wprowadzeniu nauczania języka ukraińskiego Wydział Szkół z Niepolskim Językiem Nauczania sprowadzał przez Biuro Eksportu i Importu Centralnego Domu Książki z USRR podręczniki dla klas od I do IV ${ }^{132}$. Dla potrzeb innych grup narodowych sprowadzano podręczniki z „bratnich”, socjalistycznych krajów: z Czechosłowacji, NRD, Węgier (dla dzieci greckich), ZSRR (dla szkolnictwa ukraińskiego). Ponieważ książki te nie były dostosowane do polskich programów nauczania, proces dydaktyczny był wyraźnie utrudniony. Nauczyciele często na własną rękę poszukiwali publikacji, które mogły ułatwić prowadzenie lekcji. Nawet Ministerstwo Oświaty starało się tworzyć listy książek pomocniczych, które można było wykorzystać w czasie zajęć w obliczu braku podręcznika ${ }^{133}$. Spotykająca się na konferencjach kadra zarządzająca szkół żydowskich podkreślała braki w zaopatrzeniu w pod-

130 Podobnie było z historią w innych szkołach mniejszościowych. AAN, Ministerstwo Oświaty, sygn. 1749, Notatka w sprawie organizacji i programu szkół z czeskim, słowackim i żydowskim językiem nauczania, s. 150.

131 AAN, Ministerstwo Oświaty, sygn. 1749, Pismo Ministerstwa Oświaty do PZWS z 8 II 1952, s. 211.

132 Ibidem, s. 255.

${ }^{133}$ K. Koźbiał, Szkoła z czeskim językiem nauczania w Kudowie Zdroju. Powstanie i funkcjonowanie w latach 1947-1953, „Kladsky Sbornik” 2002, nr 5, s. 180. 
ręczniki i pomoce naukowe: „Nie było takiego okresu, w którym wszystkie klasy byłyby jednocześnie zaopatrzone w czytanki i wypisy"134. W przypadku szkolnictwa greckiego i macedońskiego zachowana korespondencja pomiędzy Ministerstwem Oświaty a PZWS wyraźnie wskazuje, że brakowało podstawowych podręczników ${ }^{135}$. Problem z podręcznikami greckimi próbowano rozwiązać importując elementarze i greckie książki z Pragi, później korzystano z podręczników wydawanych w Budapeszcie. Dopiero w 1956 roku Państwowe Zakłady Wydawnictw Szkolnych wydały elementarze i czytanki w języku greckim i macedońskim dla klas II i VII, gramatykę oraz wypisy do szkół średnich w języku greckim. Wypisy te obejmowały twórczość pisarzy i poetów macedońskich oraz utwory klasyków literatury światowej, w tym polskich i rosyjskich. Szkolnictwo dla poszczególnych mniejszości (Niemców, Greków, Czechów, Ukraińców, Żydów) nie tylko rozwijało się w różnym tempie, $\mathrm{w}$ różnych okresach, ale przede wszystkim miało swoją określoną specyfikę, która wymuszała „modyfikowanie” aktów prawnych (np. zarządzeń Ministerstwa Oświaty) regulujących i organizujących placówki oświatowe. Zmiany sytuacji międzynarodowej i zmiany polityczne w PRL też nie pozostawały bez wpływu na ten proces. Nie ma natomiast wątpliwości, że przez cały omawiany okres (oprócz krótkiego okresu funkcjonowania szkół żydowskich pod egidą CKŻP) edukacja mniejszości narodowych znajdowała się pod wpływem i kontrolą państwa. Szczególną opieką edukacyjną, a zwłaszcza opiekuńczo-wychowawczą, objęte były dzieci greckie i macedońskie. Jako emigranci z socjalistycznego „bratniego” kraju były traktowane przez państwo w sposób uprzywilejowany. Ministerstwo Oświaty starało się monitorować proces ich edukacji nie tylko w szkołach podstawowych, ale także w liceach lub technikach. Świadczą o tym ministerialne wnioski składane do PWRN we Wrocławiu, aby urzędnicy „objęli opieką” młodych Greków i Macedończyków ${ }^{136}$. Przypominano także o konieczności prowadzenia zajęć pozaszkolnych w domach dziecka, które

${ }^{134}$ AP Wrocław, PWRN KOS, sygn. XVII/88, Konferencja kierowników i dyrektorów szkół z żydowskim językiem nauczania Wrocław 4 VI 1953, s. 83.

135 Pismo PZWS do MO o wydanie gramatyki języka greckiego, Macedońscy uchodźcy $w$ Polsce..., t. 2, s. 70.

136 Okólnik Ministerstwa Oświaty do WO PWRN we Wrocławiu w sprawie dalszej opieki nad dziećmi greckimi i macedońskimi, Macedońscy uchodźcy w Polsce..., t. 2, s. 26. 
zamieszkiwali emigranci, w wymiarze 2 godzin tygodniowo z podziałem na poziomy i grupy narodowe ${ }^{137}$. Postępująca asymilacja tych grup spowodowała zaniknięcie klas greckich i macedońskich. Szkoły czeskie i niemieckie zamknięto ze względu na emigrację uczniów. Podobnie było ze szkołami żydowskimi, którym ostateczny kres położył rok szkolny 1968/69. Przez cały okres PRL istniało natomiast (i funkcjonuje do dziś) legnickie liceum z ukraińskim językiem nauczania.

137 Ibidem, s. 58. 
